\title{
The tumor suppressor neurofibromin confers sensitivity to apoptosis by Ras-dependent and Ras-independent pathways
}

\author{
S Shapira ${ }^{1}$, B Barkan ${ }^{1}$, E Fridman ${ }^{2,3}$, Y Kloog ${ }^{1}$ and R Stein ${ }^{*, 1}$
}

Neurofibromatosis type 1 (NF1) is characterized by a high incidence of benign and malignant tumors attributed to loss of function of Nf1, which encodes neurofibromin, a tumor suppressor with Ras-GAP activity. Neurofibromin deficiency typically causes chronic activation of Ras, considered the major contributor to manifestation of NF1. Resistance to radio- and chemotherapy are typical of NF1-associated tumors, but the underlying mechanism is unknown. Here, we investigated interrelationships between neurofibromin expression, Ras activity, and sensitivity to apoptosis. Neurofibromin-deficient mouse embryonic fibroblasts (MEFs) and human NF1 tumor cells were more resistant than neurofibromin-expressing cells to apoptosis. Moreover, $\mathrm{Nf1}^{-I-}$, $\mathrm{Nf1}^{+l-}$, and $\mathrm{Nf1}^{+I+}$ MEFs exhibited gene-dosage-related resistance to apoptosis. Resistance of the Nf1-deficient cells was mediated by two survival pathways: a Ras-dependent pathway, and a Ras-independent pathway promoted by the lack of an NF1GRD-independent proapoptotic action of neurofibromin. Therefore, besides its Ras-dependent growth inhibition, neurofibromin can exert tumor suppression via a proapoptotic effect.

Cell Death and Differentiation (2007) 14, 895-906. doi:10.1038/sj.cdd.4402057; published online 10 November 2006

Neurofibromatosis type 1 (NF1) is an autosomal dominant disorder affecting the nervous system. It is characterized by a high incidence of benign and malignant tumors. Nf1 encodes neurofibromin, a tumor suppressor with Ras-GTPase activating protein (GAP) activity ${ }^{1}$ that facilitates the hydrolysis of GTP by active Ras-GTP. ${ }^{2-4}$ Neurofibromin deficiency results in an increase in Ras-GTP and increased activation of its effectors. $^{2-5}$ These abnormalities contribute to cell transformation in NF1 patients. ${ }^{3,4}$ Studies in Nf1-deficient mice, ${ }^{6-8}$ and Drosophila flies ${ }^{9}$ provide additional support for the significance of aberrant Ras-GTP in NF1. Notably, the GAPrelated domain of neurofibromin (NF1-GRD) may not be the only neurofibromin domain underlying disease manifestations; for example, restoration of Ras signaling in Nf1 null mutant Drosophila flies does not correct the defect in body size, ${ }^{10}$ and expression of neurofibromin in melanoma and NIH 3T3 cells inhibits their growth without affecting Ras-GTP levels. ${ }^{11}$ Ras-GAP-independent functions of neurofibromin include regulation of adenylyl cyclase activity, ${ }^{10,12}$ although neurofibromin can regulate adenylyl cyclase by a Rasdependent pathway as well. ${ }^{13}$

In view of the tumor suppressor activity of neurofibromin and the role of other tumor suppressors such as $p 53^{14}$ and DAP-kinase ${ }^{15}$ in apoptosis and tumorigenesis, we postulate that neurofibromin, in addition to its role in controlling cell proliferation, also regulates cell susceptibility to apoptosis. The proposed proapoptotic function of neurofibromin could be mediated via its regulation of Ras, since Ras pathways reportedly elicit antiapoptotic effects. ${ }^{16-18}$ This notion is supported by the observations that various $\mathrm{Nf1}$-deficient cells survive in the absence of trophic factors ${ }^{19}$ and that enhanced survival of Nf1-deficient sensory neurons is dependent on Ras. ${ }^{19-21}$ It is nevertheless possible that the proapoptotic action of neurofibromin is also exerted independently of Ras. The aim of the present study was to verify the existence of a proapoptotic action of neurofibromin, and - if confirmed - to determine the extent to which this putative action is dependent on Ras. Our results showed that neurofibromin-deficient cells are more resistant than neurofibromin-expressing cells to apoptosis. This resistance could be counteracted by inhibition of Ras activity in apoptosis induced by trophic factor deprivation but not by other triggers. Thus, neurofibromin confers sensitivity to apoptosis via Ras-dependent and independent pathways.

\section{Results}

Characterization of SV40-immortalized MEFs comprised of the three $\mathbf{N f 1}$ genotypes. Cell susceptibility to apoptosis was studied in both primary and SV40-immortalized mouse

\footnotetext{
${ }^{1}$ Department of Neurobiochemistry, George S. Wise Faculty of Life Sciences, Tel Aviv University, Ramat Aviv, Israel; ${ }^{2}$ Sackler Faculty of Medicine, Tel Aviv University, Tel Aviv, Israel and ${ }^{3}$ Susanne Levy Gertner Oncogenetics Unit, Sheba Medical Center, Tel Hashomer, Israel

*Corresponding author: R Stein, Department of Neurobiochemistry, George S. Wise Faculty of Life Sciences, Tel Aviv University, 69978 Ramat Aviv, Israel. Tel: 9723 640 8608; Fax: 9723640 7643; E-mail: reuvens@post.tau.ac.il

Keywords: neurofibromin; neurofibromatosis type 1; apoptosis; Ras; Ras-inhibitors; cAMP

Abbreviations: Ac-DEVD-7AMC, Ac-Asp-Glu-Val-Asp-7-amino-4-methylcoumarin Ac-DEVD-7AMC; ERK, extracellular signal-regulated kinase; DMEM, Dulbecco'smodified Eagle's medium; DN, dominant negative; FTS, farnesylthiosalicylic acid; GAP, GTPase activating protein; GFP, green fluorescent protein; GRD, GAP-related domain; IBMX, 3-isobutyl-1-methylxanthine; MEF, mouse embryonic fibroblast; MPNST, malignant peripheral nerve sheath tumor; MTT, 3-(4,5-dimethylthiazol-2-yl)-2,5diphenyltetrazolium bromide; NF1, neurofibromatosis type 1; PI3-kinase, phosphatidylinositol-3-kinase; RBD, Ras-binding domain; SEAP, secreted alkaline phosphatase; TBS, Tris-buffered saline; UV, ultra-violet; XIAP, X-linked inhibitor of apoptosis

Received 17.5.06; revised 04.9.06; accepted 19.9.06; Edited by J Cleveland; published online 10.11.06
} 
embryonic fibroblasts (MEFs) possessing the three Nf1 genotypes $\mathrm{Nf1^{-/- }}, \mathrm{Nf1^{+/- }}$, and $\mathrm{Nf1^{+/+ }}$. This experimental system enables us to study the effects of different dosages of the $\mathrm{Nf1}$ gene $\left(\mathrm{Nf1}^{-/-}, \mathrm{Nf1^{+/- }}\right.$, and $\left.\mathrm{Nf1^{+/+ }}\right)$ on cell susceptibility to apoptosis and on Ras signaling pathways in a defined genetic background.

$\mathrm{Nf1}^{+/-}$mice ${ }^{22}$ were mated to obtain primary MEF cultures of the three $N f 1$ genotypes. These cultures were utilized to establish SV40-immortalized MEFs (hereafter termed SV40 MEFs). Expression levels of neurofibromin in the three Nf1 SV40 MEFs genotypes were consistent with their genotypes (Figure 1a). Furthermore, their signaling properties were consistent with those reported for their corresponding primary MEFs. ${ }^{23,24}$ Accordingly, the steady-state levels of Ras-GTP, phosphorylated extracellular signal-regulated kinase (ERK), phosphorylated Akt/PKB, and phosphorylated mTOR in SV40 MEFs grown in $0.5 \%$ serum (hereafter termed serum-starved cells) were significantly higher in the $\mathrm{Nf1}^{-/-}$than in the $\mathrm{Nf1}^{+/+}$ genotype (Figure $1 \mathrm{a}$ and b). The $\mathrm{Nf} 1^{+/-}$SV40 MEFs exhibited intermediate amounts of both active Ras and its downstream active targets (Figure $1 a$ and $b$ ). Analysis of DNA synthesis in the three Nf1 SV40 MEF genotypes by the $\left[{ }^{3} \mathrm{H}\right]$ thymidine incorporation assay revealed that the rate of DNA synthesis was highest in the $\mathrm{Nf}^{-/-}$, intermediate in the $\mathrm{Nf1}^{+/-}$, and lowest in the $\mathrm{Nf1}+\mathrm{I}$ SV40 MEFs (Figure 1c). Thus, the three Nf1 SV40 MEF genotypes had retained the signaling properties of their primary MEF counterparts and could therefore be considered a suitable model system.

Neurofibromin deficiency causes resistance to apoptosis. Next, we examined susceptibilities of the three Nf1 genotypes of the primary and SV40 MEFs to apoptosis induced by staurosporine, ultra-violet (UV) radiation, and the chemotherapeutic agent vincristine. The cells were incubated for 6.5 and $24 \mathrm{~h}$ with or without staurosporine, or incubated for 15 and $24 \mathrm{~h}$ with or without vincristine, or UVirradiated or not irradiated and then maintained for an additional $15 \mathrm{~h}$ in culture. Cell viability was then determined by the 3-(4,5-dimethylthiazol-2-yl)-2,5-diphenyltetrazolium bromide (MTT) assay. The resistance of the $\mathrm{Nf}^{-1-}$ genotypes of both the primary and the SV40 MEFs to each of the three apoptotic stimuli were relatively high compared to the resistance of their respective $\mathrm{Nf1} 1^{+/+}$primary and SV40 MEFs, while the $\mathrm{Nf1}^{+/-}$primary and SV40 MEFs exhibited an intermediate resistance (Figure 2a). We further assessed the effects of the different apoptotic stimuli on cell viability in the SV40 MEFs by the Trypan blue dye exclusion assay, which measures both live and dead cells. The percentage of
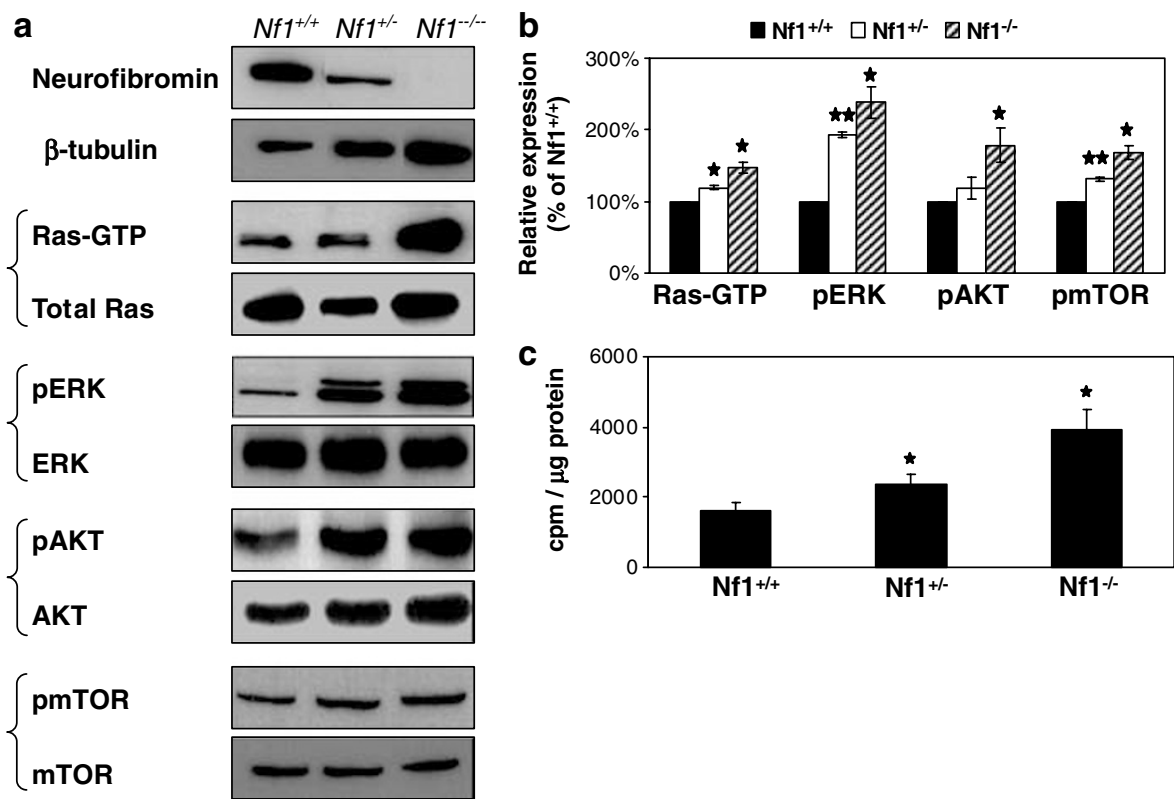

Figure 1 Effect of Nf1 gene dosage on the steady-state levels of Ras-GTP, phosphorylated ERK (pERK), phosphorylated AKT (pAKT), phosphorylated mTOR (pmTOR) (a and b) and on $\left[{ }^{3} \mathrm{H}\right]$ thymidine incorporation (c) in the three Nf1 SV40 MEF genotypes. (a) $\mathrm{Nf}^{-/-}, \mathrm{Nf}^{+/-}$, and $\mathrm{Nf}^{+/+}$SV40 MEFs were grown in medium supplemented with $0.5 \%$ serum for $18 \mathrm{~h}$. Protein extracts prepared from these serum-starved cells were subjected to immunoblot analysis for Ras (Total Ras), pERK, ERK, pAKT, AKT, pmTOR, and mTOR expression or to a RAS-GTP pull-down assay followed by immunoblot analysis for Ras (Ras-GTP), as described in Materials and Methods. Neurofibromin expression was determined in the protein extracts prepared from the three Nf1 SV40 MEF genotypes grown in the presence of serum. Membranes of the neurofibromin immunoblots were reprobed with $\beta$-tubulin to assess the uniformity of sample loading. The results shown are from a representative experiment (one of three independent experiments). (b) Quantitative analysis of Ras-GTP, pERK, pAKT, and pmTOR. Immunoblots from each of the three independent experiments were scanned and the intensity of each of the Ras-GTP, pERK, pAKT, and pmTOR bands was quantified by densitometry and normalized relative to the expression of their corresponding total Ras, ERK, AKT, or mTOR proteins. The normalized Ras-GTP, pERK, pAKT, or pmTOR value for each Nf1 genotype is expressed as a percentage of the corresponding normalized value in $\mathrm{Nf}^{+1+}$ SV40 MEFs. The values shown are means \pm S.D. (bars) $(n=3) .{ }^{*} P<0.05,{ }^{* \star} P<0.005$, significantly different from $\mathrm{Nf} 1^{+l+}$ MEFs. (c) $\left[{ }^{3} \mathrm{H}\right]$ thymidine incorporation in $\mathrm{Nf}^{-l-}, \mathrm{Nf1}^{+-}$, and $\mathrm{Nf1} 1^{+1+}$ SV40 MEFs. Cells were grown in medium supplemented with $0.5 \%$ serum. After $13 \mathrm{~h}$ the medium was replaced with medium supplemented with $1 \%$ serum and the cells were grown for an additional $1 \mathrm{~h}$. $\left[{ }^{3} \mathrm{H}\right]$ thymidine was then added to the medium and the cells were grown for an additional $8 \mathrm{~h}$. The amount of $\left[{ }^{3} \mathrm{H}\right]$ thymidine incorporated into the DNA was then determined as described in Materials and Methods. The values shown are means \pm S.D. (bars) $(n=3)$. ${ }^{*} P<0.05$, significantly different from $\mathrm{Nf1}^{+/+} \mathrm{MEFs}$ 
dead cells observed in the $N f 1^{-1-}$ SV40 MEFs was significantly lower than that observed in the $\mathrm{Nf1}{ }^{+1+} \mathrm{SV} 40$ MEFs, and the percentage in the $\mathrm{Nf}^{+}{ }^{+-}$SV40 MEFs was again intermediate between the two (Figure $2 b$ ). Combined, these results suggest that neurofibromin deficiency renders the cells resistant to the abovementioned apoptotic stimuli, and that the SV40 MEFs retained the neurofibromindependent responses to apoptosis exhibited by the primary MEFs. All subsequent experiments were therefore carried out with the SV40 MEFs.

We next examined the extent of caspase-associated apoptosis employing the DEVDase activity assay, which measures the activity of caspase-3 and -7 . Each of the apoptotic stimuli induced an increase in DEVDase activity; the increase observed was significantly lower in the $\mathrm{Nf1}^{-/-}$than in the $\mathrm{Nf}^{+1+}$ SV40 MEFs, and was intermediate in the $\mathrm{Nf1}^{+/-}$ SV40 MEFs (Figure 2c). These results are in line with those obtained with the MTT and Trypan blue assays, and further demonstrate a positive correlation between neurofibromin deficiency and resistance to apoptosis. We also measured cell viability by the colony formation assay, in which the true number of cells that remained viable following the apoptotic stimulus is determined. This last assay was carried using staurosporine as a representative apoptotic stimulus. Staurosporine was removed after the treatment and the cells were then detached from the plates and replated at low density to allow colony formation. In agreement with the results obtained by the short-term cell-death and viability assays, the colony formation assay showed that the resistance to staurosporine was highest in the $\mathrm{Nf1}^{-1-}$, intermediate in the $\mathrm{Nf1}^{+/-}$, and lowest in the $\mathrm{Nf}^{+1+}$ SV40 MEFs (Figure 2d).

These results suggest that the absence of neurofibromin promotes survival, and therefore that neurofibromin might act as a sensitizer of apoptosis. The resistance to apoptosis caused by neurofibromin deficiency might be attributable to an inherent decrease in the apoptotic potential of $\mathrm{Nf}^{-/-}$cells resulting from a decrease in the expression of proapoptotic proteins or an increase in expression of antiapoptotic proteins or both. This did not appear to be the case since the basal expression levels of $\mathrm{Bcl}-2$ family proteins (the antiapoptotic proteins $\mathrm{Bcl}-\mathrm{X}_{\mathrm{L}}$ and $\mathrm{Mcl}-1$ and the proapoptotic proteins $\mathrm{Bax}$ and Bak); caspases (the initiator caspases - caspase-8 and 9, and the effector caspase, caspase-3); and the X-linked inhibitor of apoptosis (XIAP) were similar in all the three Nf1 SV40 MEF genotypes (Figure 2e and f). Thus, the observed resistance of neurofibromin-deficient MEFs to apoptosis was not acquired as a result of changes in the expression levels of at least these key apoptotic components.

Effects of Ras inhibitors on the susceptibility of Nf1 SV40 MEF genotypes to apoptosis. The resistance of $\mathrm{Nf1}^{-1-}$ MEFs to apoptosis could have been acquired as a result of an increase in Ras-mediated survival signaling, in which case the resistance to apoptosis would be abolished by inhibition of Ras activity. We therefore examined the impact of three independent Ras inhibitors (the Ras inhibitor FTS, ${ }^{25}$ the dominant-negative (DN) Ras mutant H-RasS17N and the NF1-GRD ${ }^{20}$ on susceptibility of the three Nf1 SV40 MEF genotypes to apoptosis.
To examine the effect of FTS, the cells were pretreated with FTS or with its vehicle for $24 \mathrm{~h}$, and then subjected to the above-mentioned apoptotic stimuli in the continuous presence of FTS or its vehicle. Cell viability was determined after each treatment by the MTT assay. FTS had no effect on resistance to apoptosis of the three genotypes treated with staurosporine, UV irradiation, or vincristine (Figure 3a). A similar lack of effect of FTS was obtained when the cells were pretreated with FTS for $48 \mathrm{~h}$ (data not shown) or when cell viability was determined by the colony formation assay using treatment with staurosporine as a representative apoptotic stimulus (data not shown).

Although FTS did not affect the susceptibility of the three Nf1 SV40 MEF genotypes to apoptosis it nevertheless inhibited growth and Ras activity of $\mathrm{Nf}^{-1-}$ SV40 MEFs. Accordingly, cell counts revealed that FTS $(75 \mu \mathrm{M}, 48 \mathrm{~h})$ inhibited the growth of all three genotypes and that the effect was most pronounced in the $N f 1^{-1-}$ genotype $(28 \pm 1.8$, $23 \pm 0.5$, and $15 \pm 0.4 \%$ inhibition in the $\mathrm{Nf1}^{-1-}, \mathrm{Nf1^{+/- }}$, and $\mathrm{Nf1}^{+/+}$genotypes, respectively). In addition, DNA synthesis $\left(\left[{ }^{3} \mathrm{H}\right]\right.$ thymidine incorporation) induced by $1 \%$ serum in $13 \mathrm{~h}$ serum-starved cells of all three genotypes was strongly inhibited by FTS (Figure 3b). Notably, the range of FTS concentrations used in these experiments and in all subsequent experiments in which cells were grown in low serum was $2.5-30 \mu \mathrm{M}$; FTS is more effective in low serum than in high serum because it binds to serum proteins; thus in low serum the concentration of free FTS is higher than in high serum. ${ }^{26-28}$ Last, FTS induced a reduction in steady-state Ras-GTP levels in the serum-starved Nf1 SV40 MEFs with no appreciable effect on total Ras levels (Figure $3 c$ and d). The extent of inhibition correlated well with the Nf1 gene dosage and with the levels of Ras-GTP shown in Figure $1 \mathrm{a}$ and $\mathrm{b}$ : the lower the gene dosage, the higher the levels of Ras-GTP and the sensitivity to FTS.

The effects of H-RasS17N and NF1-GRD on the susceptibility of $\mathrm{Nf}^{-1-}$ and $\mathrm{Nf1} 1^{+/}$SV40 MEFs to apoptosis were assayed in secreted alkaline phosphatase (SEAP)/HRasS17N or SEAP/NF1-GRD co-transfectants. Empty vectors pcDNA3 or pac served, respectively, as controls. The cells were treated $18 \mathrm{~h}$ after transfection, with staurosporine for 6.5 or $24 \mathrm{~h}$ and cell viability was then determined by monitoring SEAP activity. Transfection with empty vectors did not alter the basic differences in the apoptotic responses of the two Nf1-genotype transfected SV40 MEFs; the $N f 1^{-1-}$ genotype remained more resistant than the $\mathrm{Nf1}{ }^{+/+}$genotype to staurosporine-induced apoptosis (Figure 4a). Similar results were obtained when the two Nf1 SV40 MEF genotypes were transfected with DN Ras or NF1-GRD; neither of these expression vectors altered the relatively higher resistance of the $\mathrm{Nf1}^{-/-}$than of the $\mathrm{Nf1} 1^{+/+}$SV40 MEFs to staurosporineinduced apoptosis (Figure 4a). The inability of DN Ras or NF1GRD to reverse the resistance of $\mathrm{Nf}^{-1-}$ and MEFs to apoptosis could not be attributed to a lack of expression or activity, since both DN Ras and NF1-GRD Nf1 ${ }^{-1-}$ SV40 MEF transfectants exhibited markedly smaller amounts of RasGTP and phosphorylated-ERK than those recorded in the vector-controlled $\mathrm{Nf}^{-1-}$ MEF transfectants (Figure $4 \mathrm{~b}$ and c). Taken together, the results obtained by three independent methods of Ras inhibition strongly suggest that the enhanced 
resistance of $\mathrm{Nf1}^{-1-}$ MEFs to apoptosis induced by the abovementioned apoptotic triggers is not mediated by Rasdependent survival signals. We therefore conclude that neurofibromin can sensitize MEFs to apoptosis by a mechanism that is independent of Ras.

Deficiency of neurofibromin causes Ras-dependent resistance of $\mathrm{Nf1}^{-1-}$ SV40 MEFs to trophic factor deprivation. Studies have shown that various $\mathrm{Nf}^{-1-}$ cell types are more resistant than $\mathrm{Nf}^{+/+}$cells to apoptosis induced by trophic factor deprivation. ${ }^{19,29}$ Therefore, we examined whether $\mathrm{Nf1}^{-1-}$ SV40 MEFs would also be more resistant than $\mathrm{Nf1} 1^{+/+}$and $\mathrm{Nf1}{ }^{+/-}$SV40 MEFs to apoptosis induced by trophic factor deprivation, and if so, whether or not this effect was dependent on Ras. The three Nf1 SV40 MEF genotypes were deprived of serum for $15 \mathrm{~h}$ and the numbers of live and dead cells were then determined by counting. Resistance to serum deprivation was found to be relatively high in the $\mathrm{Nf1}^{-/-}$, relatively low in the $\mathrm{Nf1} 1^{+/+}$and intermediate in the $\mathrm{Nf1}^{+/-}$SV40 MEFs (Figure 5a). These results thus show that the absence of neurofibromin also causes resistance to apoptosis induced by trophic factor deprivation in the $\mathrm{Nf}^{-1-}$ SV40 MEFs.

Next, we examined whether this survival effect is dependent on Ras activity. Examination of the effect of $2.5 \mu \mathrm{M}$ FTS, which reduced Ras-GTP levels in all three serum-starved Nf1 SV40 MEF genotypes (Figure $5 b$ and c), on cell death induced by the serum deprivation showed that FTS had overcome the a

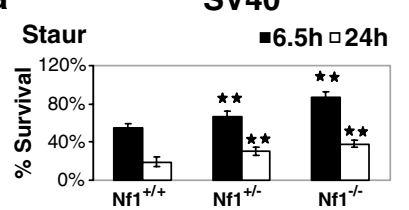

UV $\quad-60 \mathrm{mj} / \mathrm{cm}^{2} \square 90 \mathrm{mj} / \mathrm{cm}^{2}$
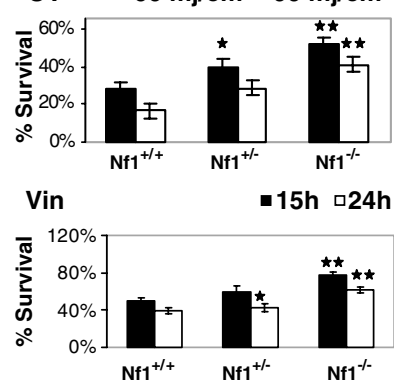

b

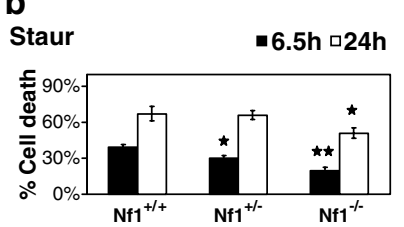

UV $\quad-60 \mathrm{mj} / \mathrm{cm}^{2} \square 90 \mathrm{mj} / \mathrm{cm}^{2}$
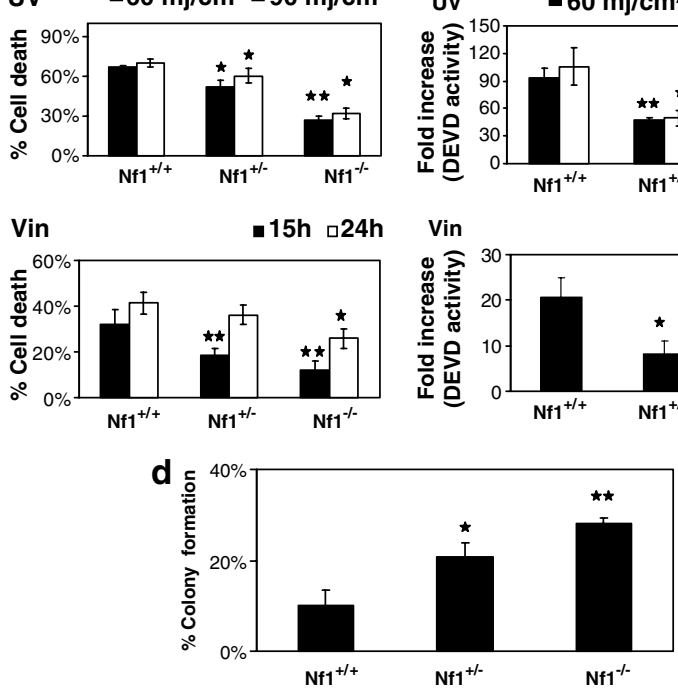

C

Staur
Primary
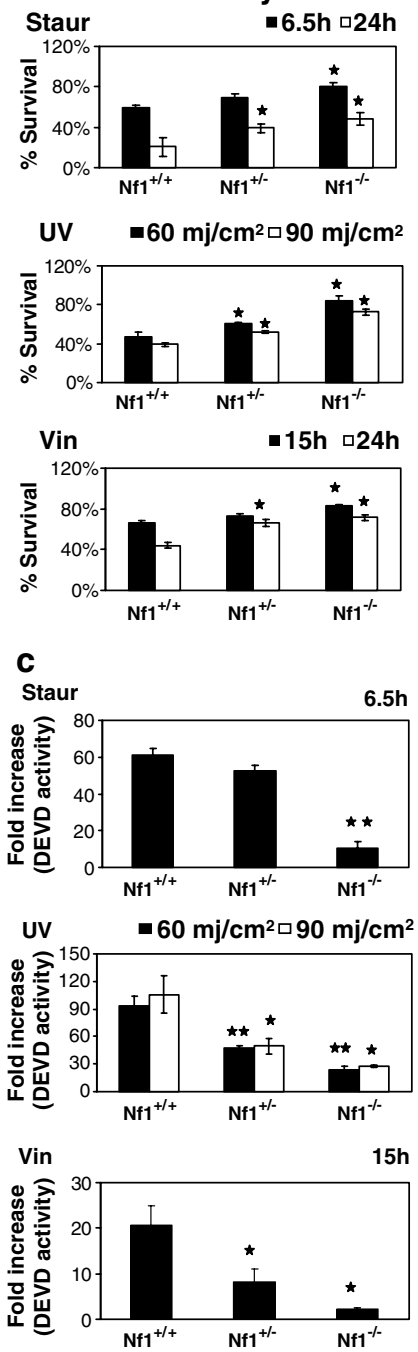

$15 \mathrm{~h}$

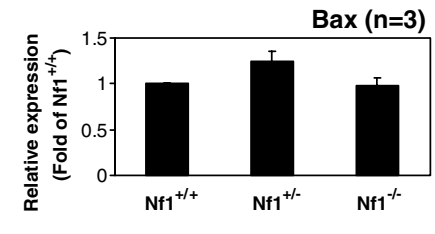

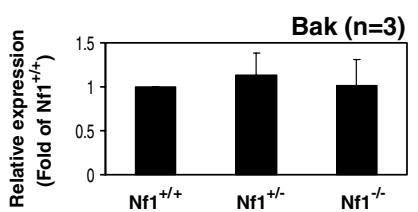

e

$\left\{\begin{array}{l}B c l-x_{L} \\ \beta \text {-tubulin }\end{array}\right.$

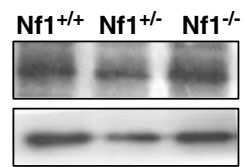

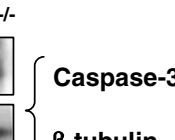

$\mathrm{Nf1} 1^{+/+} \mathrm{Nf} 1^{+/-} \mathrm{Nf} 1^{-/-}$

Mcl-1

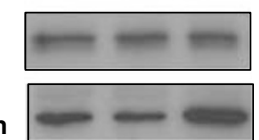

$\beta$-tubulin

Caspase-8

$\beta$-tubulin

$\left\{\begin{array}{l}\text { Bax } \\ \beta \text {-tubulin }\end{array}\right.$

$\left\{\begin{array}{l}\text { Bak } \\ \beta \text {-tubulin }\end{array}\right.$

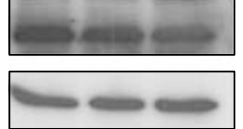

XIAP

$\beta$-tubulin
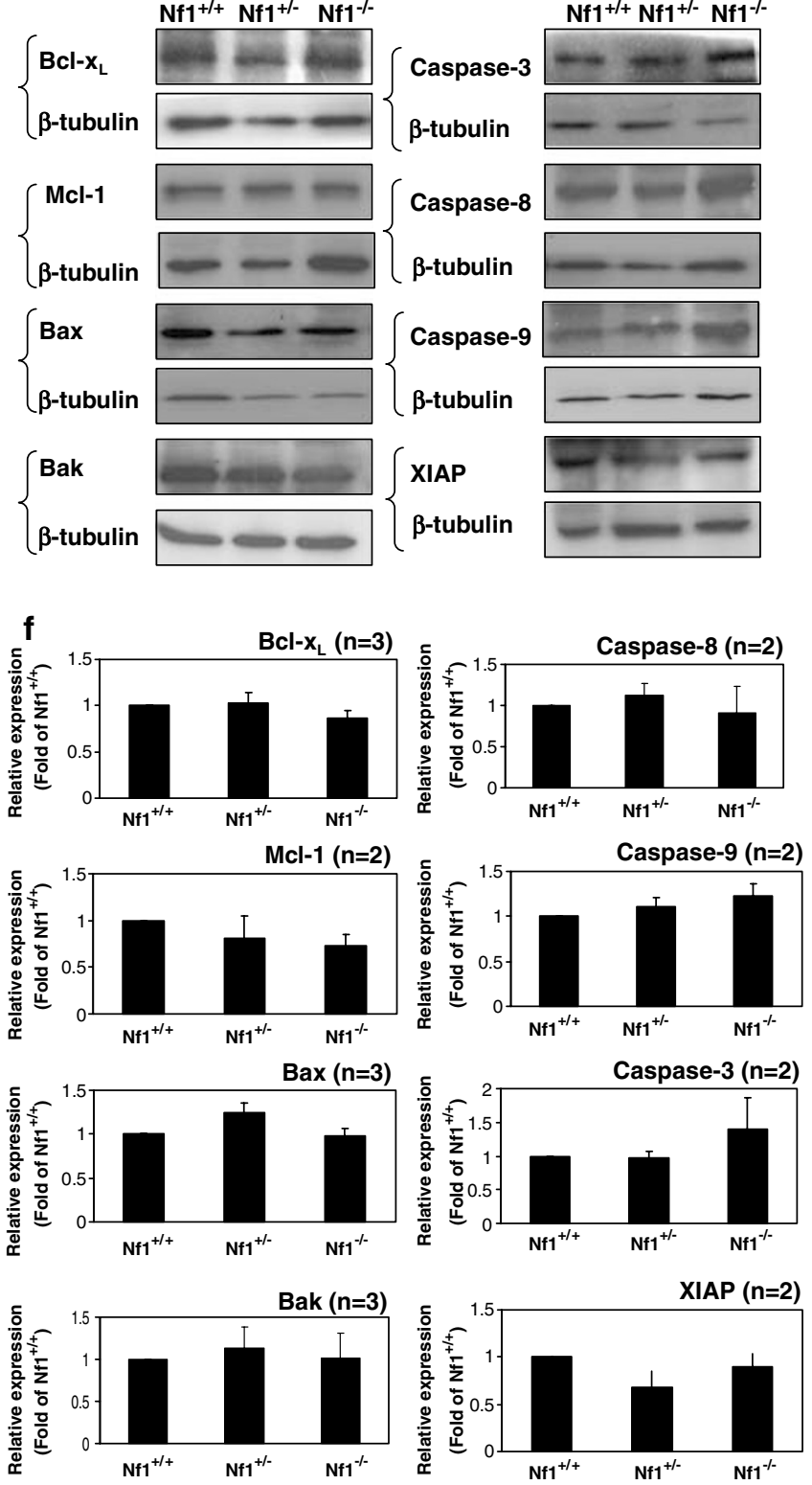

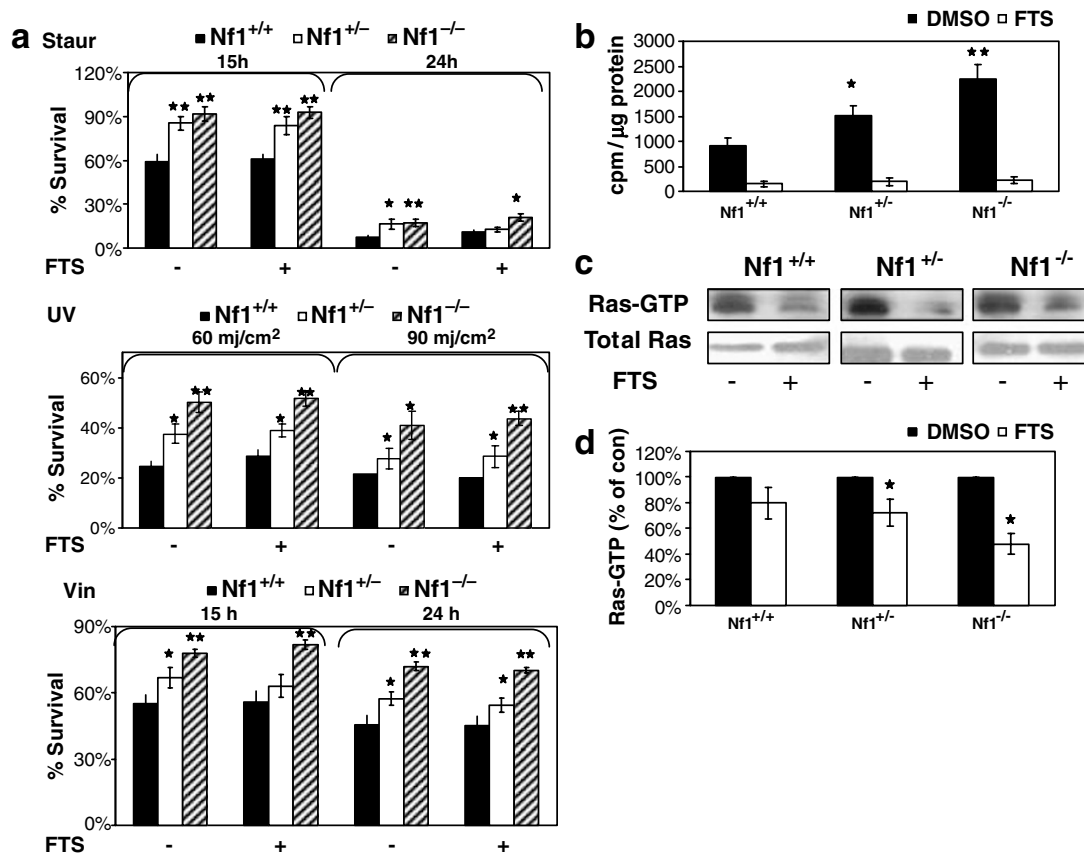

Figure 3 Effects of FTS on cell susceptibility to apoptosis, Ras-GTP levels, DNA synthesis, and cell growth in the three Nf1 SV40 MEF genotypes. (a) Effect of FTS on cell susceptibility to apoptosis. $\mathrm{Nf}^{-/-}, \mathrm{Nf1}^{+/-}$, and $\mathrm{Nf}^{+/+}$SV40 MEFs were pretreated with $75 \mu \mathrm{M} \mathrm{FTS}$ or its vehicle $(0.1 \%$ DMSO) for $24 \mathrm{~h}$ and were then left untreated or were treated with Staur or Vinc or were UV-irradiated, as described in Figure 2, in the continuous presence of FTS $(+)$ or DMSO $(-)$. Cell viability after treatments was determined by the MTT assay. Survival was defined as the MTT value after each apoptotic treatment in each of the Nf1 SV40 MEF genotypes, in the presence of DMSO or FTS, expressed as a percentage of the MTT value obtained in the corresponding Nf1 SV40 MEF genotype in the absence of the apoptotic treatment but in the presence of DMSO or FTS. Values are means \pm S.D. (bars) $(n=3) .{ }^{*} P<0.05,{ }^{* *} P<0.005$, significantly different from the corresponding treatment in $\mathrm{Nf}^{+}{ }^{+l+} \mathrm{MEFs}$. (b) Effect of FTS on steady-state Ras-GTP. The three Nf1 SV40 MEF genotypes were grown in medium supplemented with $0.5 \%$ serum for $18 \mathrm{~h}$ in the presence of $5 \mu \mathrm{M}$ FTS $(+)$ or its vehicle $(0.1 \% \mathrm{DMSO})(-)$. Protein extracts were then prepared and the amount of Ras in each treatment was determined by immunoblot analysis. Ras-GTP was determined by the Ras pull-down assay. The results shown are from a representative experiment (one of three independent experiments). (c) Quantitative analysis of Ras-GTP. Intensities of the Ras-GTP bands in the different treatments were quantified by densitometry and normalized relative to total Ras expression for each Nf1 genotype. The normalized Ras-GTP value in each of the FTS-treated Nf1 SV40 MEF genotypes is expressed as a percentage of the normalized Ras-GTP value in the corresponding Nf1 SV40 MEF genotype treated with DMSO. Values shown are means \pm S.D. (bars) $(n=3) .{ }^{*} P<0.05$, significantly different from the DMSO-treated MEFs. (d) Effect of FTS on $\left[{ }^{3} \mathrm{H}\right]$ thymidine incorporation in the three Nf1 SV40 MEF genotypes. Cells were grown in medium supplemented with $0.5 \%$ serum. After $13 \mathrm{~h}$ the medium was replaced with medium supplemented with $1 \%$ serum containing either $30 \mu \mathrm{M} \mathrm{FTS}$ or $0.1 \%$ DMSO and the cells were grown for an additional hour. $\left[{ }^{3} \mathrm{H}\right.$ ] thymidine was then added to the medium and the cells were grown for an additional $8 \mathrm{~h}$ in the continuous presence of FTS or DMSO. The amount of $\left[{ }^{3} \mathrm{H}\right]$ thymidine incorporated into the DNA was then determined as described in Materials and Methods. The values shown are means \pm S.D. (bars) $(n=3) .{ }^{*} P<0.05,{ }^{* \star} P<0.005$, significantly different from DMSO-treated cells

\footnotetext{
Figure $2 \mathrm{Nf1^{-1- }}$ MEFs are more resistant than $\mathrm{Nf1}^{+/-}$or $\mathrm{Nf1} 1^{+/+}$MEFs to cytotoxic drugs. SV40 (a-d) and primary (a) $\mathrm{Nf1}{ }^{-1-}, \mathrm{Nf1} 1^{+/-}$, and $\mathrm{Nf1} 1^{+1+} \mathrm{MEFs}$ were treated without or with staurosporine (Staur) $(0.5 \mu \mathrm{M})$ or vincristine (Vinc) $(0.07 \mu \mathrm{M})$ for the indicated times, or were UV-irradiated at the indicated intensities or not irradiated, and then grown for $15 \mathrm{~h}$ after which cell survival or death was determined. (a) Determination of cell viability in the different Nf1-genotype SV40 and primary MEFs by the MTT assay, performed as described in Materials and Methods. Survival was defined as the MTT value after each apoptotic treatment in each of the three Nf1 SV40 MEF genotypes, expressed as a percentage of the MTT values obtained in the absence of apoptotic treatment at the corresponding time points or UV irradiation intensities. The values shown are means \pm S.D. (bars) $(n=3) .{ }^{\star} P<0.05,{ }^{\star \star} * P<0.005$, significantly different from the corresponding treatment in $N f 1^{+1+}$ MEFs. (b) Determination of cell death and viability in the three Nf1 SV40 MEF genotypes by the Trypan blue assay. After treatment with the apoptotic stimuli, blue (dead) and white (live) cells were counted under the microscope. Cell death was defined as the number of blue cells, expressed as a percentage of the total number of cells (blue and white) in each treatment. The values shown are means \pm S.D. (bars) $(n=3)$. ${ }^{*} P<0.05,{ }^{*} P<0.005$, significantly different from the corresponding treatments in $N f 1^{+1+}$ SV40 MEFs. (c) DEVDase activity in SV40 MEFs. The three Nf1 SV40 MEF genotypes were left untreated or were treated with Staur $(0.5 \mu \mathrm{M})$ or Vinc $(0.07 \mu \mathrm{M})$ for the indicated times, or were grown for $15 \mathrm{~h}$ with or without prior UV irradiation. DEVDase activity was assayed as described in Materials and Methods. The results are expressed as the ratio of DEVDase activity measured after each type of apoptotic treatment in each Nf1 genotype to the corresponding activity measured in the untreated cells. The values shown are from a representative experiment $(n=3)$. (d) Determination of cell viability by colony formation. The three Nf1 SV40 MEF genotypes were treated with Staur $(0.5 \mu \mathrm{M})$ for $6.5 \mathrm{~h}$, and surviving cells were then allowed to form colonies as described in Materials and Methods. Colony formation for each Nf1 genotype was defined as the number of clones obtained after treatment with Staur, expressed as a percentage of the number obtained in untreated cultures. The values shown are means \pm S.D. $(n=3)$. ${ }^{*} P<0.05,{ }^{* *} P<0.005$, significantly different

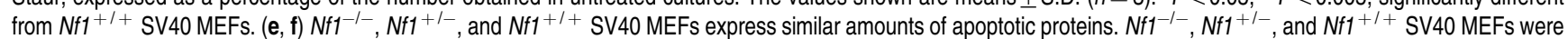
grown in medium supplemented with $10 \%$ serum. (e) Protein extracts prepared from these cells were subjected to immunoblot analysis for Bcl- $x_{L}, \mathrm{Mcl}-1, \mathrm{Bax}, \mathrm{Bak}, \mathrm{caspase}-8$, $-9,-3$, and XIAP expression, as described in Materials and Methods. Membranes of immunoblots were reprobed with $\beta$-tubulin to assess the uniformity of sample loading. The results shown are from a representative experiment (one of two or three independent experiments). (f) Quantitative analysis of Bcl- $\mathrm{x}_{\mathrm{L}}, \mathrm{Mcl}-1, \mathrm{Bax}, \mathrm{Bak}, \mathrm{caspase}-8,-9,-3$, and XIAP expression. Immunoblots from each of the different independent experiments were scanned and the intensity of each of the apoptotic bands was quantified by densitometry and normalized relative to the expression of their corresponding $\beta$-tubulin proteins. The normalized apoptotic proteins value for each $N f 1$ genotype is expressed as the fold increase of the corresponding normalized value in $N f 1^{+l+}$ SV40 MEFs. Values shown are means \pm S.D. (bars) $(n=3)$ or means \pm range (bars) $(n=2)$
} 


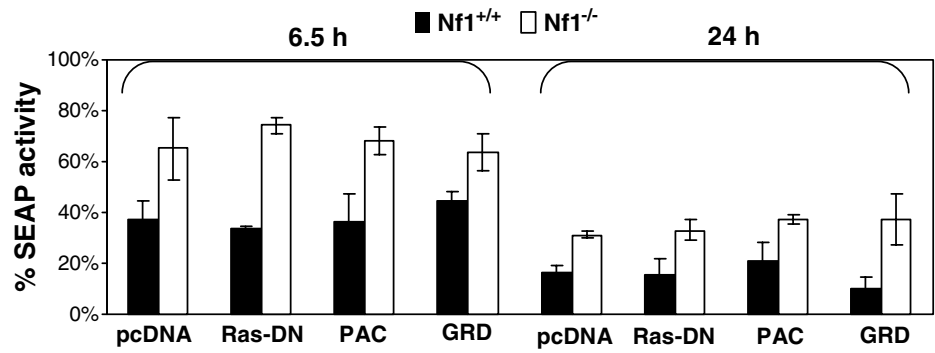

b
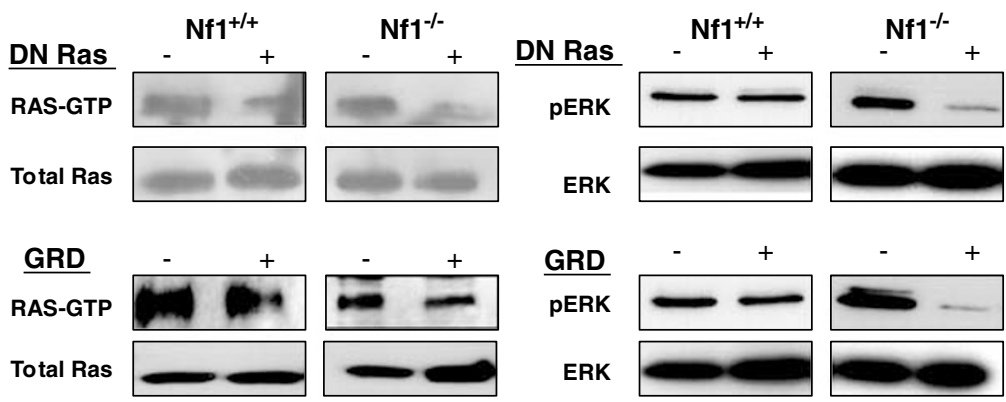

GRD

PERK

ERK
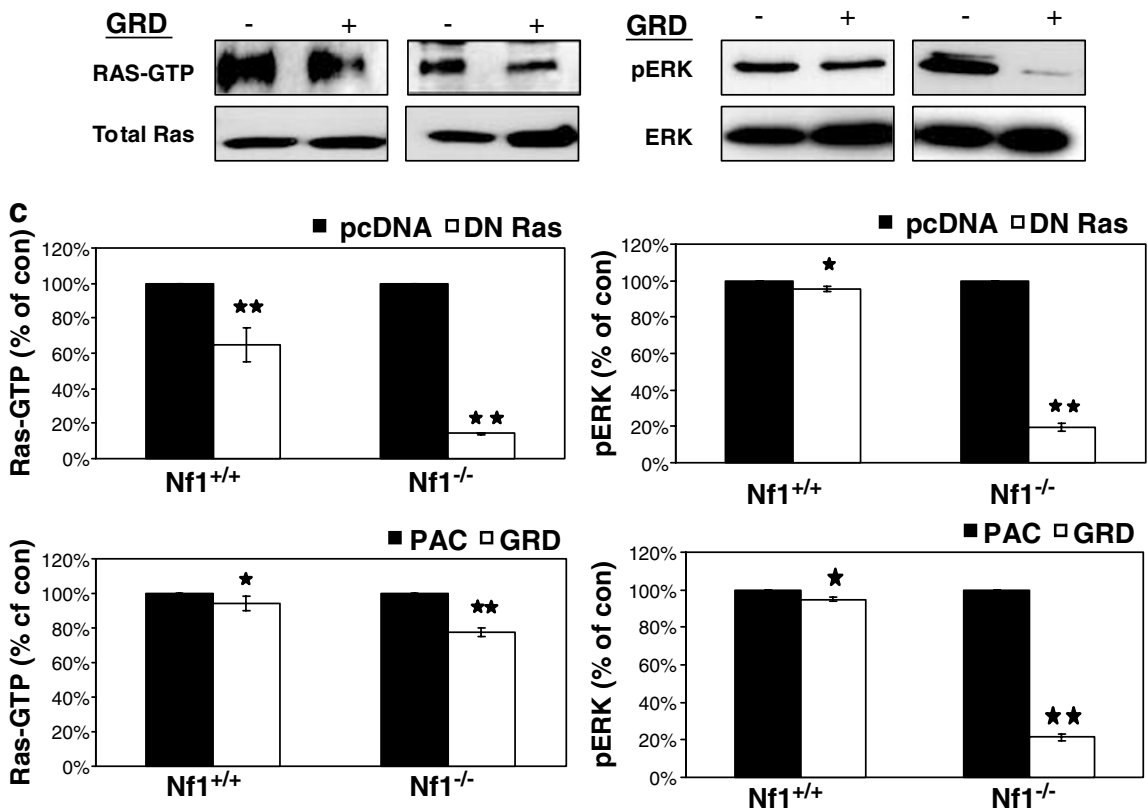

Figure 4 Effects of DN Ras or NF1-GRD expression on cell viability, Ras-GTP levels, and ERK phosphorylation. Nf1 ${ }^{-1-}$ and Nf1 ${ }^{+1+}$ SV40 MEFs were co-transfected with SEAP and with DN Ras, NF1-GRD, pcDNA3, or PAC expression vectors, as described in Materials and Methods. (a) After $18 \mathrm{~h}$ the transfected cultures were treated with Staur $(0.5 \mu \mathrm{M})$ for 6.5 or $24 \mathrm{~h}$ or were left untreated, and viability of the transfected cells was determined by measurement of SEAP activity in the culture medium, as described in Materials and Methods. Cell survival was defined as SEAP activity in the Staur-treated transfected cultures and is expressed as a percentage of the SEAP activity in the Staur-untreated transfected cultures. (b) Protein extract was prepared from Staur-untreated transfected cultures $24 \mathrm{~h}$ after the addition of Staur to their sister cultures, and the expression levels of Ras-GTP, Ras, pERK, and ERK were determined as described in Figure 1. Values shown are from a representative experiment $(n=3)$. (c) Ras-GTP and pERK were quantitatively analyzed by densitometry and were normalized relative to the expression levels of total Ras and ERK, as described in Figure 1. The normalized RasGTP or pERK values in each transfection are expressed as percentages of Ras-GTP or pERK values in cells transfected with the corresponding control empty vector (pcDNA3 or PAC). Values shown are means \pm S.D. (bars) $(n=3)$. ${ }^{\star} P<0.05,{ }^{* \star} P<0.005$, significantly different from pcDNA3- or PAC-transfected cells

relative resistance of both the $\mathrm{Nf1}^{-1-}$ and the $\mathrm{Nf1^{+/- }}$ MEFs to death (Figure 5a). This finding suggests that the increased resistance of neurofibromin-deficient MEFs to trophic factor deprivation is attributed to the increase in Ras activity. This contention was further supported by co-transfection experiments with DN Ras. $\mathrm{Nf1}^{-1-}, \mathrm{Nf1^{+/- }}$, and $\mathrm{Nf1} 1^{+/+}$SV40 MEFs were each co-transfected with SEAP and the H-RasS17N expression vectors and $18 \mathrm{~h}$ later were deprived of serum for $24 \mathrm{~h}$. The empty pcDNA3 vector served as a control. Cell viability was then determined by monitoring SEAP activity. Transfection with the empty vector did not alter the basic differences in sensitivity of the three genotypes of SV40 MEFs to serum deprivation: resistance to serum deprivation was found to be relatively high in the $\mathrm{Nf}^{-/-}$, relatively low in the $\mathrm{Nf1} 1^{+/+}$and intermediate in the $\mathrm{Nf1} 1^{+/-}$SV40 MEFs (Figure 5d). Transfection with DN Ras, however, overcame the relative resistance of both the $N f 1^{-1-}$ and the $N f 1^{+/-}$ MEFs to cell death induced by serum deprivation (Figure $5 d$ ). This latter finding indicated that DN Ras, like FTS, promotes serum-deprived cell death in both $\mathrm{Nf}^{-1-}$ and $\mathrm{Nf1} 1^{+/-}$MEFs but not in $\mathrm{Nf1} 1^{+1+}$ MEFs, further supporting the conclusion that the increased resistance of neurofibromin-deficient MEFs to trophic factor deprivation is attributable to the increase in Ras activity. These results taken together with those obtained 


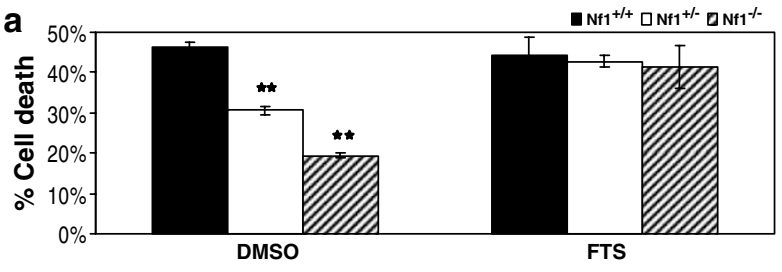

b

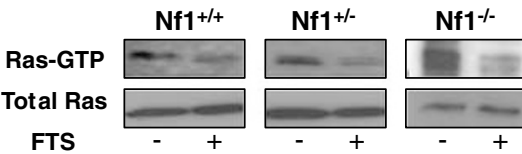

C
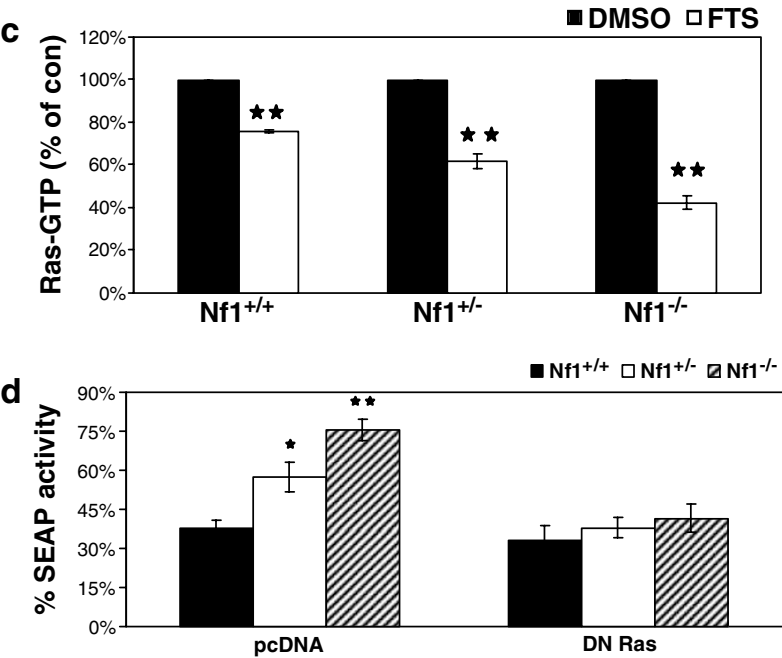

Figure 5 Ras inhibitors inhibit the enhanced resistance of $\mathrm{Nf}^{-1-}$ SV40 MEFs to apoptosis induced by serum deprivation. (a) Effect of FTS on cell viability. $\mathrm{Nf1}^{-1-}$, $\mathrm{Nf1} 1^{+/-}$, and $\mathrm{Nf}^{+1+}$ SV40 MEFs were grown in serum-free medium for $15 \mathrm{~h}$ in the presence of DMSO $(0.005 \%)$ or $2.5 \mu \mathrm{M}$ FTS. Live and dead cells were counted using the Trypan blue assay and percentage cell death was defined as described in Figure $2 b$. Values shown are means \pm S.D. (bars) $(n=3)$. ${ }^{* *} P<0.005$, significantly different from the corresponding treatments in Nf1 $1^{+1+}$ MEFs. (b, c) Effect of FTS on steady-state levels of Ras-GTP. Nf1 $1^{-1-}, \mathrm{Nf}^{+/-}$, and $\mathrm{Nf1} 1^{+l+}$ SV40 MEFs were grown in medium supplemented with $0.5 \%$ serum for $15 \mathrm{~h}$ in the presence of DMSO $(0.005 \%)$ or $2.5 \mu \mathrm{M}$ FTS. Protein extracts were then prepared and (a) the amounts of Ras and Ras-GTP in each treatment were determined as described in Figure 1. The results shown are from a representative experiment (one of three independent experiments). (c) Quantitative analysis of Ras-GTP. Intensities of the Ras-GTP bands obtained after the different treatments in the three independent experiments were quantified by densitometry and normalized relative to total Ras expression for each Nf1 genotype. The normalized Ras-GTP value in each of the FTS-treated Nf1 SV40 MEF genotypes is expressed as a percentage of the normalized Ras-GTP value in the corresponding DMSO-treated Nf1 SV40 MEF genotype. Values shown are means \pm S.D. (bars) $(n=3) .{ }^{* \star} P<0.005$, significantly different from the DMSO-treated MEFs. (d) Effect of DN Ras on cell viability. Nf1 ${ }^{-1}$ and $\mathrm{Nf}^{+1+}$ SV40 MEFs were co-transfected with SEAP and with DN Ras or pcDNA3 expression vectors, as described in Materials and Methods. After $18 \mathrm{~h}$, the transfected cells were deprived of serum as described in Materials and Methods, or were left in serum-supplemented medium. They were then allowed to grow for $24 \mathrm{~h}$ longer, and their viabilities were determined by measurement of SEAP activity in the culture medium, as described in Materials and Methods. Cell survival was defined as SEAP activity in the serum-deprived transfected cultures and is expressed as a percentage of the SEAP activity in the corresponding transfected cultures gown in the presence of serum. Values shown are means \pm S.D. (bars) $(n=3)$. ${ }^{*} P<0.05$, ${ }^{\star *} P<0.005$, significantly different from $p c D N A 3$-transfected cells

with cytotoxic treatments suggest that neurofibromin promotes proapoptotic effects in MEFs via both Ras-dependent and Ras-independent pathways.
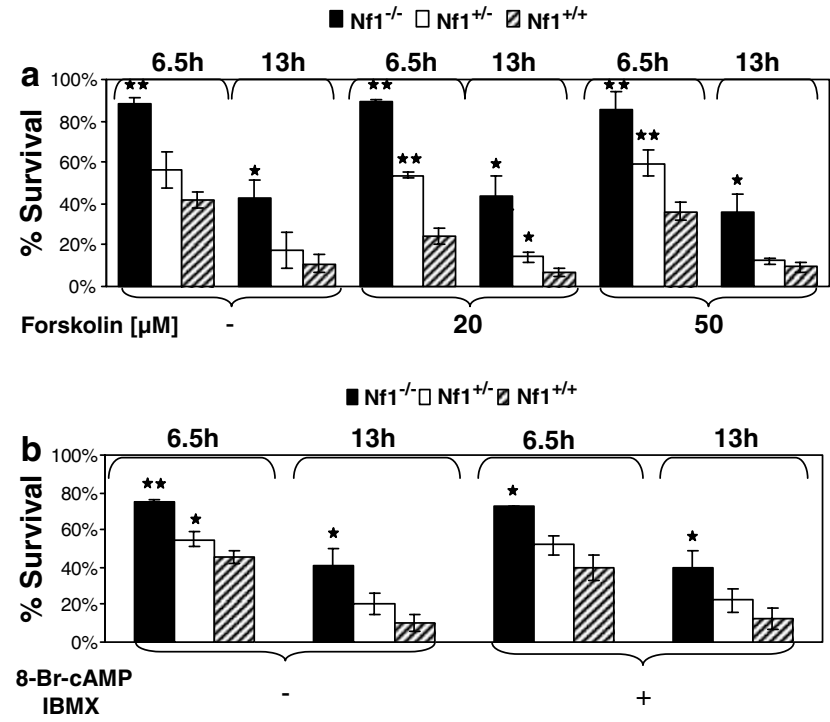

Figure 6 Effect of forskolin (a) and 8-Br-cAMP (b) on the susceptibility of $\mathrm{Nf1}^{-1-}$, $\mathrm{Nf1}{ }^{+/-}$, and $\mathrm{Nf} 1^{+/+}$SV40 MEFs to Staur. The three Nf1 SV40 MEF genotypes were pretreated for $1 \mathrm{~h}$ without $(-)$ or with the indicated concentrations of forskolin or with 8Br-cAMP $(100 \mu \mathrm{M})$ and IBMX $(200 \mu \mathrm{M})$, and were then treated with Staur $(0.5 \mu \mathrm{M})$ or left untreated for the indicated times. Cell viability was determined by the MTT assay. Survival was defined as the MTT values obtained in cultures treated with Staur in the presence or absence of forskolin or 8-Br-CAMP and IBMX, expressed as a percentage of the MTT values obtained in the corresponding control cultures treated in the absence of Staur and in the presence or absence of forskolin or 8-Br-cAMP and IBMX. The values shown are means \pm S.D. (bars) $(n=3)$. ${ }^{*} P<0.05,{ }^{* \star} P<0.005$, significantly different from the corresponding treatment in Nf1 ${ }^{+1+}$ MEFs

Ras-independent resistance of $\mathrm{Nf1}^{-/}$MEFs to apoptosis is not mediated by the absence of cAMP. Neurofibromin reportedly promotes cAMP production by a domain distinct from the NF1-GRD. ${ }^{10,12}$ These data, together with the reported evidence of cAMPpromoted apoptosis in T cells, ${ }^{30}$ led us to suspect that the resistance of $\mathrm{Nf1}^{-1-}$ MEFs to apoptosis might be conferred by defective cAMP production. We therefore, examined whether an increase in CAMP in $\mathrm{Nf}^{-1-}$ MEFs can reduce the resistance of these cells to apoptosis. The three Nf1 SV40 MEF genotypes were pretreated for $1 \mathrm{~h}$ with forskolin (a direct activator of adenylyl cyclase) or with the cellpermeable cAMP analog 8-Br-cAMP, together with 3-isobutyl-1-methylxanthine (IBMX) (an inhibitor of phosphodiesterases, which degrade cAMP). The cells were then exposed to staurosporine for 6.5 or $13 \mathrm{~h}$ and cell viability was determined by the MTT assay. Neither forskolin nor 8-Br-cAMP affected the susceptibility of the three Nf1 SV40 MEF genotypes to apoptosis induced by staurosporine (Figure 6) although in all three Nf1 SV40 MEF genotypes, we observed a marked increase in cAMP levels (data not shown). These results suggest that the effect of neurofibromin on Ras-independent cell susceptibility to apoptosis is not mediated by cAMP.

Ras-dependent and Ras-independent survival of neurofibromin-deficient human MPNST cells. Next, we examined whether the differences in resistance to apoptosis 
observed between the three Nf1 MEF genotypes were also detectable between the MPNST ST88-14 ( $\left.\mathrm{Nf1}^{-1-}\right)$, and the STS26T $\left(\mathrm{Nf1}^{+/+}\right)$schwannomas. ${ }^{27}$ ST88-14 and STS26T cells were treated with staurosporine or vincristine or exposed to UV irradiation and their viability was determined by the MTT assay. The Nf1-deficient ST88-14 schwannoma cells were significantly more resistant than the $\mathrm{Nf1}^{+/+}$ STS26T schwannoma cells to apoptosis induced by each of these triggers (Figure 7a). Similar results were obtained when we assessed the survival of staurosporine-treated

a $_{\text {Staur }}$
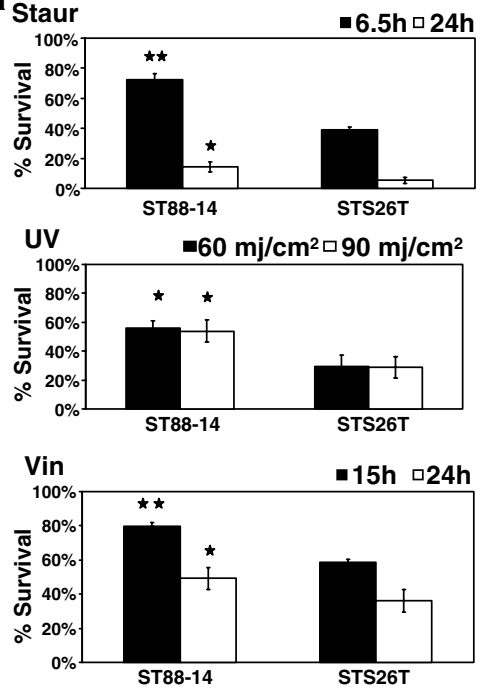

b

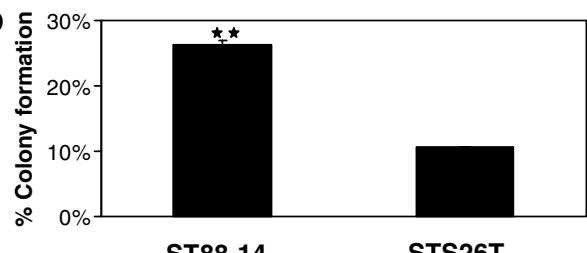

C
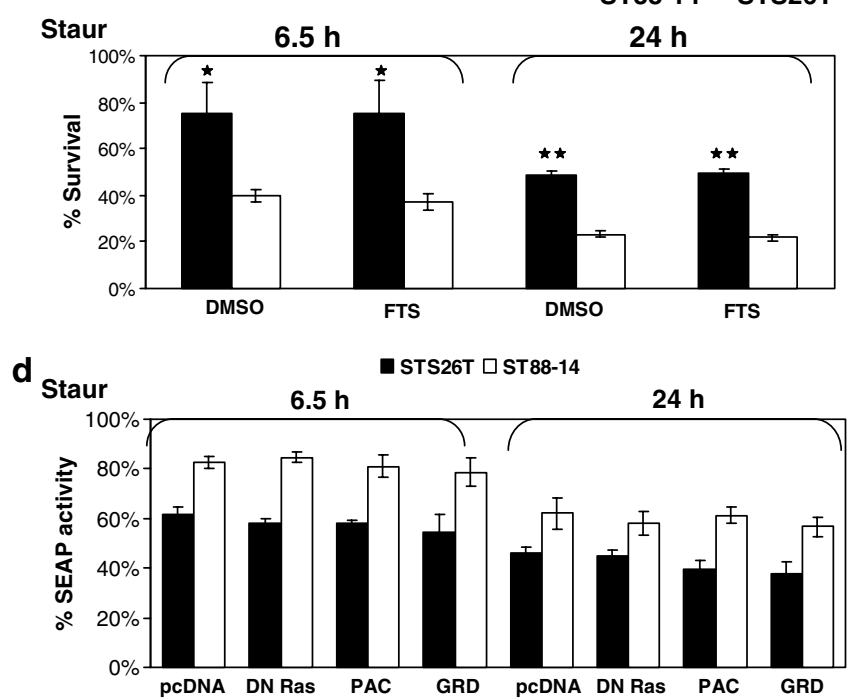

ST88-14 and STS26T schwannomas using the colonyformation assay (Figure $7 \mathrm{~b}$ ).

Next, we investigated the role of Ras and of cAMP on the increased resistance of the Nf1-deficient ST88-14 schwannoma cells to apoptosis by examining the effects of FTS, DN Ras, NF1-GRD, forskolin, and 8-Br-cAMP on the susceptibility of ST88-14 and STS26T schwannomas to staurosporine-induced apoptosis, as described above for the MEFs. The results showed that the increased resistance to staurosporine-induced apoptosis of ST88-14 cells was not abolished by
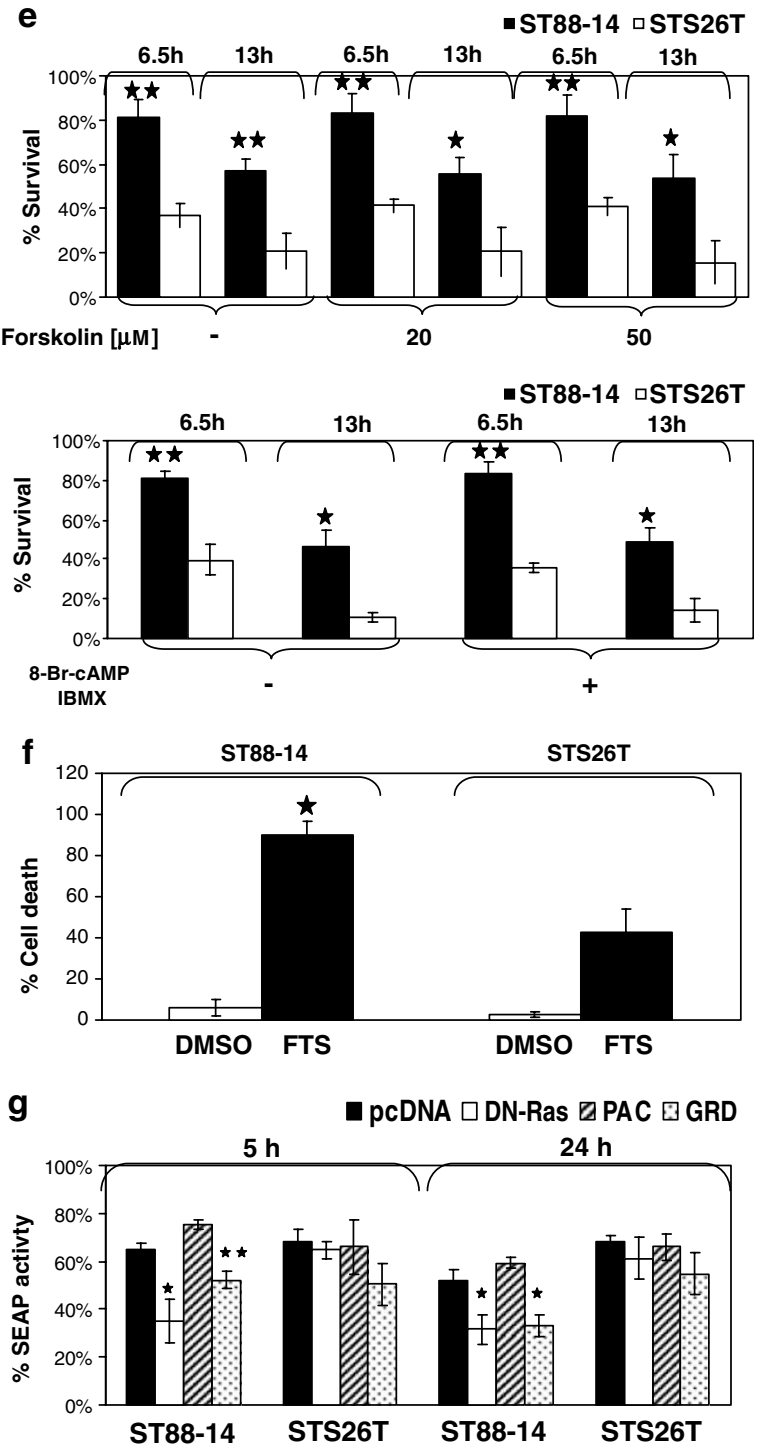
FTS (Figure 7c), DN Ras, or NF1-GRD (Figure 7d), nor by forskolin or 8-Br-cAMP (Figure 7e). Thus, as in the case of the MEFs, the human Nf1-deficient schwannoma cells exhibited enhanced resistance to apoptosis induced by staurosporine, vincristine, or UV irradiation, and this resistance appeared to be independent of both Ras and cAMP at least in the case of apoptosis induced by staurosporine.

Next, we examined whether, by analogy to the SV40 MEFs, the Nf1-deficient ST88-14 cells exhibit enhanced Rasdependent survival when challenged by trophic factor deprivation. Recently, we showed that FTS effectively reduces steady-state levels of Ras-GTP and inhibits growth of ST88-14 cells. $^{27}$ We therefore treated serum-starved ST88-14 and STS26T cells with FTS or with its vehicle for $24 \mathrm{~h}$, and then determined the numbers of live and dead cells. In the absence of FTS, the serum-starved ST88-14 and STS26T cells showed similar viability (Figure 7f) possibly because the survival of these two schwannoma cell lines under these conditions is dependent on numerous factors in addition to the presence of neurofibromin. Nonetheless, the ST88-14 cells were more sensitive than the STS26T cells to the effects of FTS (Figure 7f). The effect of Ras on the viability of ST88-14 and STS26T cells under conditions of trophic factor deprivation was further examined in serum-deprived ST88-14 and STS26T cells transfected with DN Ras, NF1GRD, or empty vectors (Figure $7 \mathrm{~g}$ ). Compared to the empty vector, DN Ras, or NF1-GRD significantly reduced the viability of serum-starved ST88-14 cells. No such reductions were observed in serum-starved STS26T-transfected cells. These results thus suggest that for survival under conditions of trophic factor deprivation, the Ras dependence of the neurofibromin-deficient ST88-14 cells is greater than that of neurofibromin-expressing STS26T cells.
Thus, neurofibromin promotes sensitivity to trophic factor deprivation-induced apoptosis by inhibiting Ras in human MPNST cells.

\section{Discussion}

The results of this study show that neurofibromin can promote sensitivity to apoptosis and that the apoptotic effect is mediated both by Ras-dependent and by Ras- and cAMPindependent pathways. This conclusion is based on the following findings: (1) In neurofibromin-deficient cells, resistance to apoptosis was enhanced, and (in the case of the MEFs) was dependent on gene dosage. (2) The enhanced resistance of neurofibromin-deficient SV40 MEFs and MPNST cells to staurosporine, UV irradiation, and vincristine was independent of Ras and CAMP, as demonstrated by the inability of Ras inhibitors or agents that elevate cAMP levels to counteract it. (3) Survival of the neurofibromin-deficient SV40 MEFs and MPNST cells in the absence of or incomplete support by growth factors was significantly dependent on Ras, as demonstrated by the ability of Ras inhibitors to increase or promote cell death under these conditions. Detection of the proapoptotic effects of neurofibromin in both MEFs and human MPNST cells suggests that they represent a general rather than a species- or cell-type-specific feature of the protein.

This study also demonstrates that $\mathrm{Nf}^{-/-}, \mathrm{Nf1} 1^{+/-}$, and $\mathrm{Nf1} 1^{+/+}$SV40 MEFs collectively serve as a useful model system for studying cellular aspects of NF1. The $\mathrm{Nf1}^{-1-} \mathrm{SV} 40$ MEFs like human NF1 MPNST cells exhibit upregulation of Ras-GTP and its signaling pathways as well as enhanced resistance to apoptosis. Furthermore, this system allows us to study the effects of different gene dosages of neurofibromin

\footnotetext{
Figure 7 NF1 MPNST cells exhibit Ras- and cAMP-independent and Ras-associated survival effects. (a) ST88-14 cells are more resistant than STS26T cells to apoptosis induced by Staur, UV, or Vinc. ST88-14 cells and STS26T cells were treated with Staur or Vinc or were left untreated for the indicated times, or were UV-irradiated at the indicated intensities and then grown for $15 \mathrm{~h}$. Viability of the treated cells was determined by the MTT assay. Survival was defined as the MTT value after each apoptotic treatment, expressed as a percentage of the MTT value in the absence of apoptotic treatment at the corresponding time point. The values shown are means \pm S.D. (bars) $(n=3)$. ${ }^{*} P<0.05,{ }^{\star *} P<0.005$, significantly different from the corresponding treatment in STS26T cells. (b) Colony formation assay of ST88-14 and STS26T cells treated with Staur $(0.5 \mu \mathrm{M})$ for $6.5 \mathrm{~h}$. Cells that survived the apoptotic treatment were allowed to form colonies, as described in Materials and Methods. Colony formation was defined as the number of clones obtained after treatment with Staur and expressed as a percentage of the number obtained in untreated cultures. The values shown are means \pm S.D. $(n=3) .{ }^{\star \star} P<0.005$, significantly different from STS26T cells. (c) Effect of FTS on the susceptibility of ST88-14 and STS26T cells to apoptosis induced by Staur. ST88-14 cells and STS26T cells were pretreated with $75 \mu \mathrm{M}$ FTS or its vehicle $(0.1 \% \mathrm{DMSO})$ for $24 \mathrm{~h}$ and were then treated with Staur or left untreated, as described in Figure 2 , in the continuous presence of FTS or DMSO. Cell viability after treatments was determined by the MTT assay. Survival was defined as the MTT value after the apoptotic treatment in each cell line, in the presence of DMSO or FTS, expressed as a percentage of the MTT value obtained in the absence of apoptotic treatment but in the presence of DMSO or FTS. The values shown are means \pm S.D. (bars) $(n=3)$. ${ }^{*} P<0.05$, ${ }^{* *} P<0.005$, significantly different from the corresponding treatment in STS26T cells. (d) Effects of DN Ras or NF1-GRD expression on the susceptibility of ST88-14 and STS26T cells to apoptosis induced by Staur. ST88-14 cells and STS26T cells were co-transfected with SEAP and with DN Ras, NF1-GRD, pcDNA3, or PAC expression vectors, as described in Materials and Methods. After $18 \mathrm{~h}$, the transfected cultures were treated with Staur as described in Figure 2 or were left untreated, and viability of the transfected cells was determined by measurement of SEAP activity in the culture medium, as described in Materials and Methods. Cell survival was defined as SEAP activity in the Staur-treated transfected cultures and is expressed as a percentage of the SEAP activity in the Stauruntreated transfected cultures. (e) cAMP does not affect the susceptibility of ST88-14 or STS26T cells to apoptosis. ST88-14 cells and STS26T cells were pretreated with forskolin $(20$ or $50 \mu \mathrm{M})$ or $8-B r-c A M P(100 \mu \mathrm{M})$ and IBMX $(200 \mu \mathrm{M})$ for $1 \mathrm{~h}$ and were then treated with Staur $(0.5 \mu \mathrm{M})$ or left untreated for the indicated times. Cell viability was determined by the MTT assay and survival was defined as described in Figure 6 . The values shown are means \pm S.D. (bars) $(n=3)$. ${ }^{*} P<0.05,{ }^{* *} P<0.005$, significantly different from the corresponding treatments in STS26T cells. Ras inhibitors sensitize ST88-14 cells to apoptosis stimulated by trophic factor withdrawal (f, $\mathbf{g})$. (f) Effect of FTS on apoptosis stimulated by serum starvation. ST88-14 cells and STS26T cells were grown in medium supplemented with $0.5 \%$ serum for $15 \mathrm{~h}$, and $20 \mu \mathrm{M} \mathrm{FTS} \mathrm{or} 0.1 \%$ DMSO was then added and the cells were grown for $24 \mathrm{~h}$ longer. Cell death was then determined by the Hoechst 33258 dye-exclusion assay, as described in Materials and Methods. Cell death in the treated cultures was defined as the number of cells stained with the Hoechst 33258 dye and expressed as a percentage of the total number of cells. The values shown are means \pm S.D. (bars) $(n=3)$. ${ }^{*} P<0.005$, significantly different from the corresponding treatments in STS26T cells. (g) Effect of DN Ras and NF1-GRD on apoptosis induced by serum deprivation. ST88-14 cells and STS26T cells were co-transfected with SEAP and with DN Ras, NF1-GRD, pcDNA3, or PAC expression vectors, as described in Materials and Methods. After $18 \mathrm{~h}$ the transfected cultures were deprived of serum for 5 or $24 \mathrm{~h}$, as described in Materials and Methods, or were left in medium supplemented with serum. Viability of the transfected cells was determined by measurement of SEAP activity in the culture medium, as described in Materials and Methods. Cell survival was defined as SEAP activity in the serum-deprived transfected cultures and is expressed as a percentage of the SEAP activity in the corresponding transfected cultures gown in the presence of serum. ${ }^{*} P<0.05,{ }^{* \star} P<0.005$, significantly different from the corresponding empty vector transfectants
} 
on cell growth and apoptosis in a defined genetic background. This is an important feature, as comparison between NF1 and non-NF1 tumors from different individuals might show different effects that could stem from differences in their genetic backgrounds. In addition, fibroblasts are among the key cell types that constitute neurofibromas. ${ }^{31}$

Our finding indicating that neurofibromin promotes NF1GRD-independent proapoptotic effects is in line with the suggestion that domain(s) other than the NF1-GRD can promote the tumor suppressor function of neurofibromin. ${ }^{11}$ Thus, neurofibromin seems to exert its tumor suppressor effect by two pathways, encoded within two different domains of the gene. One pathway is associated with cell growth inhibition and is encoded by the NF1-GRD, while the other is associated with apoptosis and is encoded via NF1-GRDs and non NF1-GRDs. Interestingly, proapoptotic action was also attributed to merlin, the tumor suppressor gene product that underlies neurofibromatosis type $2 .{ }^{32,33}$

To the best of our knowledge the NF1-GRD- and CAMPindependent proapoptotic action of neurofibromin is a novel, hitherto unknown function of this protein. This new function has important potential for extending our understanding of NF1 and hence facilitating its treatment. The enhanced resistance of neurofibromin-deficient cells to apoptosis might underlie, at least in part, the lack of response of NF1 patients to cytotoxic drugs and could have significant implications for NF1 therapy. First, it is necessary to re-evaluate the use and efficacy of cytotoxic drugs for the treatment of NF1-associated tumors. Secondly, treatment of NF1-associated tumors with Ras inhibitors alone might not be sufficient to sensitize the cells to commonly used cytotoxic drugs. It seems that treatment, to be beneficial, should include the combined utilization of a Ras inhibitor and a cytotoxic drug capable of bypassing the proapoptotic step affected by neurofibromin. The design of such drugs requires understanding of the mechanism whereby neurofibromin deficiency confers resistance to apoptosis. Our finding that the expression levels of key apoptotic components were similar in neurofibrominexpressing and -deficient MEFs suggested that the increased resistance to apoptosis of neurofibromin-deficient cells is mediated not by an inherent enhancement in their apoptotic threshold due to changes in the expression levels of key apoptotic proteins (at least those examined in the present study), but rather by the lack of a more direct proapoptotic action of neurofibromin. The mechanism, as well as the specific neurofibromin domain within which this proapoptotic activity is contained, have yet to be determined. Such studies are currently in progress in our laboratory.

\section{Materials and Methods}

Materials. All reagents were purchased from Sigma (St Louis, MO, USA) unless otherwise stated. Ac-Asp-Glu-Val-Asp-7-amino-4-methylcoumarin (Ac-DEVD7AMC) was from Biomol Research Laboratories (Plymouth Meeting, PA, USA). Farnesylthiosalicyic acid (FTS) was prepared as previously described in detail. ${ }^{34}$

Antibodies. Rabbit anti-neurofibromin polyclonal antibody (Ab) (BL956) was purchased from Bethyl Laboratories (Montgomery, TX, USA). Rabbit anti-Bcl-X, mouse anti-caspase-9, rabbit anti-Akt, rabbit anti-phospho Akt (S473), rabbit antimTOR, and rabbit anti-phospho mTOR (S2448) Abs were purchased from Cell Signaling Technology (Danvers, MA, USA). Rabbit anti-caspase-3 and rabbit antiERK (c-14) Abs were purchased from Santa Cruz Biotechnology (Santa Cruz, CA,
USA). Mouse anti-phospho ERK monoclonal antibody (mAb) was purchased from Sigma. Mouse anti-Pan Ras mAb (Ab-3) was purchased from Calbiochem (La Jolla, CA, USA). Rabbit anti-Bax-NT and rabbit anti-Bak-NT Abs were purchased from Upstate Cell Signaling Solutions (Charlottesville, VA, USA). Rat anti-caspase-8 was purchased from Alexis Biochemicals (San Diego, CA, USA). Mouse anti-XIAP was purchased from BD Transduction Laboratories (Lexington, KY, USA).

Cell culture. Human NF1 ST88-14 MPNST, non-NF1 STS26T schwannoma, and the different primary and SV40-immortalized $\mathrm{Nf1}$ genotypes $\left(\mathrm{Nf} 1^{+l+}, \mathrm{Nf}^{+l-}\right.$, and $\mathrm{Nf}^{-1-}$ ) of MEFs were grown in high-glucose Dulbecco's-modified Eagle's medium (DMEM) supplemented with 10\% heat-inactivated fetal calf serum (both from Biological Industries, Beit Ha Emek, Israel) with $0.0004 \% \beta$-mercaptoethanol added to the MEF growth medium only. In serum-starvation or serum-deprivation experiments the cells were detached from the plates, centrifuged, washed once with PBS, resuspended in DMEM without serum or with $0.5 \%$ serum, respectively, and then seeded in 96-well or six-well plates in the presence or absence of DMSO or FTS.

Transgenic Nf1 mice and preparation of primary mouse embryonic fibroblasts. C57BL/6J mice with a targeted Nf1 gene allele were obtained from Dr N Ratner (University of Cincinnati Medical School, Cincinnati, $\mathrm{OH}, \mathrm{USA})^{22}$ To obtain the three $\mathrm{Nf1}$ genotypes $\left(\mathrm{Nf}^{+/+}, \mathrm{Nf1}^{+/-}\right.$, and $\mathrm{Nf}^{-1-}$ ), $\mathrm{Nf}^{+l-}$ mice were mated and checked for the presence of a copulatory plug. To obtain embryos, pregnant mice were killed after 11.5 days (the day the plug was observed was designated as day 0.5). Embryos were transferred to a sterile dish, washed in PBS, their internal organs were removed, and the rest of the embryo was chopped into small pieces that were then incubated with trypsin/EDTA for $40 \mathrm{~min}$ at $37^{\circ} \mathrm{C}$ and $8 \% \mathrm{CO}_{2}$, followed by centrifugation at $1000 \times g$. The resulting pellets were resuspended in growth medium and the cells were seeded in $10-\mathrm{cm}$ plates. After $4 \mathrm{~h}$ the medium was changed and the attached surviving fibroblasts were allowed to grow further. The genotypes of the different embryos were determined by PCR using the appropriate primer set as described. ${ }^{22}$

Generation of SV40-immortalized MEFs. The three primary Nf1 MEF genotypes were immortalized by transfection with SV40 whole genome DNA (a gift from Dr Atan Gross, The Weizmann Institute of Science) using the lipofectamine transfection reagent (InvitroGen Life Technologies, Paisley, UK). At 1 day before transfection, primary MEFs were seeded at a density of $2 \times 10^{5}$ cells per well in sixwell plates. To each dish, we added $1 \mathrm{ml}$ of DNA-lipofectamine mixture, $2 \mu \mathrm{g}$ DNA $(1 \mu \mathrm{g} \mathrm{SV} 40$ whole genome DNA and $1 \mu \mathrm{g}$ pcDNA3 DNA) and $10 \mu \mathrm{g}$ of lipofectamine in $1 \mathrm{ml}$ of OptiMEM (InvitroGen), according to the manufacturer's instructions. The cells were split $24 \mathrm{~h}$ after transfection and seeded in $10-\mathrm{cm}^{2}$ dishes at a density of $1 \times 10^{3}$ to $1 \times 10^{4}$ cells per dish. Immortalized clones from each $N f 1$ genotype were collected 14 days after transfection. For each of the three genotypes at least three different clones, obtained from different batches of primary cultures, were analyzed for their Ras signaling pathways and susceptibility to apoptosis, and all yielded similar results. For further analysis, clones $\mathrm{c1}\left(\mathrm{Nf}^{-l-}\right), \mathrm{C7}\left(\mathrm{Nf}^{+/-}\right)$, and $\mathrm{C7}$ $\left(\mathrm{Nf1} 1^{+1+}\right)$ were chosen as representative clones for the immortalized Nf1 MEF genotypes and were designated SV40 Nf1 $1^{-1-} \mathrm{MEF}, \mathrm{SV} 40 \mathrm{Nf1}{ }^{+l-} \mathrm{MEF}$, and SV40 $\mathrm{Nf1}{ }^{+1+} \mathrm{MEF}$, respectively.

Plasmids. The expression vectors pEGFP, pcDNA3, pCMV-SEAP, and pRSV H-Ras(S17N) (DN-Ras) have been described elsewhere. ${ }^{35,36}$ The MSCV-NF1GRD vector and its empty puromycin resistance gene $(\mathrm{Pac})$ vector were obtained from $\mathrm{Dr}$. D Wade Clapp (Indiana University School of Medicine).

Transfection. At 1 day before transfection, the three Nf1 SV 40 MEF genotypes and the schwannoma cell lines were seeded at a density of $2 \times 10^{5}$ cells per well in six-well plates or in $35-\mathrm{mm}$ dishes. The SV40 MEFs were transfected by the lipofectamine reagent. To each well or dish, we added $1 \mathrm{ml}$ of DNA-lipofectamine mixture (InvitroGen) as described above. The cells were co-transfected with SEAP and GFP using either the DN-RAS or the NF1-GAP expression vectors. After incubation of the cells with the DNA-lipofectamine mixture for $18 \mathrm{~h}$, DMEM supplemented with $10 \%$ serum with or without staurosporine was added, and incubation was continued for 6.5 or $24 \mathrm{~h}$. The schwannoma cell lines were transfected by the FuGENE 6 reagent (Roche Diagnostics, Mannheim, Germany). To each dish, we added $1 \mathrm{ml}$ of DNAFuGENE mixture, $2 \mu \mathrm{g} \mathrm{DNA}$, and $3 \mu \mathrm{l}$ of FuGENE 6 in $1 \mathrm{ml}$ of OptiMEM, according to the manufacturer's instructions. The ratios of the DNA vectors used for transfection were $0.43: 0.43: 1: 1$ for DN-Ras/ 
pEGFP/SEAP/pcDNA3 plasmids, $1: 0.3: 0.7$ for pcDNA3/pEGFP/SEAP plasmids, $1: 0.3: 0.7$ for NF1-GAP/pEGFP/SEAP plasmids, and $1: 0.3: 0.7$ for Pac/pEGFP/ SEAP plasmids.

Ras-GTP assays. Cells were lysed with Ras-binding domain (RBD) lysis buffer containing $50 \mathrm{mM}$ Tris- $\mathrm{HCl}(\mathrm{pH} 7.6), 20 \mathrm{mM} \mathrm{MgCl}_{2}, 200 \mathrm{mM} \mathrm{NaCl}, 0.5 \% \mathrm{NP} 40$, $1 \mathrm{mM}$ DTT, $1 \mathrm{mM}$ antiproteases, and $0.1 \mathrm{mM}$ orthovanadate. Lysates containing $1 \mathrm{mg}$ protein were analyzed for Ras-GTP by the glutathione $S$-transferase-Rasbinding domain pull-down assay followed by Western immunoblotting with pan antiRas antibodies, as described previously. ${ }^{36}$

Immunoblotting. Total extracts (100 $\mu$ g protein) from each treatment were separated by 7.5 and $12.5 \%$ SDS-PAGE and electroblotted onto supported nitrocellulose. Each blot was blocked for $1 \mathrm{~h}$ in $10 \mathrm{mM}$ Tris base, $150 \mathrm{mM} \mathrm{NaCl}$, and $0.05 \%$ Tween-20 (TBST) containing 5\% fat-free milk, and then incubated with a primary antibody overnight at $4^{\circ} \mathrm{C}$. The membranes were then washed three times (10 min each) with TBST and this was followed by incubation for $1 \mathrm{~h}$ at room temperature with the appropriate secondary $\mathrm{Ab}$ (goat anti-mouse; donkey anti-rat, or goat anti-rabbit IgG peroxidase conjugate; Jackson ImmunoResearch Laboratories, West Grove, PA, USA). The blots were developed using the Supersignal West Pico chemiluminescence kit (Pierce Biotechnology, Rockford, IL, USA). Each blot was reprobed with $\beta$-tubulin, ERK, mTOR, or AKT to verify that protein was uniformly loaded across the gel.

\section{Assessment of cell survival}

Trypan blue. Cells were detached from the plate and resuspended in $0.4 \%$ Trypan blue solution. White and blue cells were then viewed and were counted microscopically using a hemacytometer.

Hoechst 33258 dye exclusion. After treatments, Hoechst $33258(1 \mu \mathrm{g} / \mathrm{ml})$ was added to the culture medium and light and fluorescence images were collected on a fluorescence microscope (Olympus, $\times 10$ objective lens) connected to a CCD camera for imaging. Cells whose nuclei were stained with the dye were counted as dead cells. The number of Hoechst 33258-positive cells was expressed as a percentage of the total number of cells.

3-(4,5-Dimethylthiazol-2-yl)-2,5-diphenyltetrazolium bromide (MTT). The numbers of live cells in the 96-well plates $\left(5 \times 10^{3}\right.$ cells per well) were determined by the MTT assay, as described elsewhere. ${ }^{37}$ Briefly, MTT was dissolved in PBS at a concentration of $5 \mathrm{mg} / \mathrm{ml}$. From this stock solution, $10 \mu \mathrm{l}$ per $100 \mu \mathrm{l}$ of medium was added to each well, after which the plates were incubated at $37^{\circ} \mathrm{C}$ for $4 \mathrm{~h}$ Acid-isopropanol ( $100 \mu \mathrm{l}$ of $0.04 \mathrm{M} \mathrm{HCl}$ in isopropanol) was then added to the well and mixed in. After $15 \mathrm{~min}$ at room temperature, the plates were read on a microELISA reader at a test wavelength of $540 \mathrm{~nm}$ and a reference wavelength of $690 \mathrm{~nm}$. SEAP activity. The three Nf1 SV40 MEF genotypes and the schwannoma cell lines were co-transfected with GFP and SEAP and with DN-Ras, NF1-GAP, pcDNA3, or the Pac expression vector, as described above. Viability of the transfected cells was determined both by measuring the activity of SEAP in the medium of the transfected cells and by estimating the number of GFP-positive cells visualized by fluorescence microscopy (data not shown). SEAP activity reflects the viability of a pool of transfected cells, whereas the number of GFP-positive cells reflects viability on a single-cell basis. In the experiments in which staurosporine was used as the apoptotic inducer the efficiency of transfection was determined by measuring SEAP activity in the medium $18 \mathrm{~h}$ after transfection, and then replacing the transfection medium with fresh medium with or without staurosporine and allowing the cells to grow for an additional $24 \mathrm{~h}$. SEAP activity was measured in each transfection 6.5 and $24 \mathrm{~h}$ after the medium was changed. These SEAP values were normalized relative to the SEAP activity measured $18 \mathrm{~h}$ after transfection (which indicated the efficiency of transfection) in each case. In the serumdeprivation experiments, the efficiency of transfection was determined by measuring SEAP activity in the medium $18 \mathrm{~h}$ after transfection. The cells were then collected by trypsinization and washed with PBS by centrifugation at $1000 \times g$. The resulting pellets were resuspended in medium supplemented with or without serum and then the cells were replated and allowed to grow for an additional $24 \mathrm{~h}$. SEAP activity was measured in each transfection 5 and $24 \mathrm{~h}$ after replating. These SEAP values were normalized relative to the SEAP activity measured $18 \mathrm{~h}$ after transfection (which indicated the efficiency of transfection) in each case. SEAP activity was assayed as described elsewhere. ${ }^{35}$ Briefly, $200 \mu$ lfom the culture medium of the transfected cells were collected and spun for $2 \mathrm{~min}$ at $10000 \times g$. The supernatant was incubated at $65^{\circ} \mathrm{C}$ for $10 \mathrm{~min}$, and aliquots $(30 \mu \mathrm{l})$ from each treatment were then incubated with $200 \mu$ of SEAP buffer ( $1 \mathrm{M}$ diethanolamine, $0.5 \mathrm{mM} \mathrm{MgCl}_{2}, 10 \mathrm{mM}$
L-homo-arginine, and $5 \mathrm{mg} / \mathrm{ml} \mathrm{p}$-nitrophenyl phosphate; at $37^{\circ} \mathrm{C}$ for about $4 \mathrm{~h}$. Assays were performed in quadruplicate for each treatment. The plates were read on a microELISA reader at a wavelength of $405 \mathrm{~nm}$.

Assay for DEVDase activity. The activity of caspase-3/-7 was measured in terms of the assayed DEVDase activity (cleavage of the fluorescent synthetic peptide Ac-DEVD-7-AMC). The three Nf1 SV40 MEF genotypes $\left(1 \times 10^{6}\right.$ cells) were treated with staurosporine or vincristine or were left untreated for the indicated times or were UV-irradiated and then grown for an additional $15 \mathrm{~h}$. At each time point the cells were collected, centrifuged, washed with PBS, and then frozen at $-70^{\circ} \mathrm{C}$. Each cell pellet was resuspended in $100 \mu$ l of extraction buffer $(50 \mathrm{mM}$ Tris$\mathrm{HCl}, \mathrm{pH} 7.4,1 \mathrm{mM}$ EDTA, and $10 \mathrm{mM} \mathrm{EGTA}$ ) and then lysed by three rounds of freezing and thawing. The extracts were centrifuged for $5 \mathrm{~min}$ at $20000 \times \mathrm{g}$. Supernatants $(150 \mu \mathrm{g}$ protein) were measured for DEVDase activity using a reaction buffer containing AC-DEVD-7-AMC $(50 \mu \mathrm{M}), 50 \mathrm{mM}$ Tris-HCl pH 7.5, $1 \mathrm{mM}$ $\mathrm{DTT}$, and $2 \mathrm{mM} \mathrm{MgCl}$. After $30 \mathrm{~min}$ at $37^{\circ} \mathrm{C}$, fluorescence was measured at $360 \mathrm{~nm}$ for excitation and $460 \mathrm{~nm}$ for emission.

Colony-formation assay. SV40 MEFs, ST88, or STS26T cells $\left(2 \times 10^{5}\right.$ cells grown in six-well plates) were treated with $0.5 \mu \mathrm{M}$ staurosporine or left untreated in the presence or absence of FTS. After $6.5 \mathrm{~h}$ the cells were detached from the plates, spun, and replated in 10-cm dishes and grown under regular growth conditions for 7-10 days. The resulting colonies were fixed with $10 \%$ acetic acid in PBS, stained with $0.4 \%$ crystal violet (dissolved in $10 \%$ acetic acid in PBS), and counted.

Incorporation of $\left[{ }^{3} \mathrm{H}\right]$ thymidine. SV40 MEFs $\left(3 \times 10^{4}\right.$ cells grown in 12 well plates) were serum starved for $13 \mathrm{~h}$, after which $1 \%$ serum was added to the cells in the presence or absence of $30 \mu \mathrm{M}$ FTS or DMSO. After incubation for $1 \mathrm{~h}$, $1 \mu \mathrm{C}_{\mathrm{j}} / \mathrm{ml}\left[{ }^{3} \mathrm{H}\right]$ thymidine was added to the cultures and the cells were grown for an additional $8 \mathrm{~h}$. The cells were then washed with ice-cold PBS, and this was followed by incubation for $15 \mathrm{~min}$ in $100 \%$ methanol at $-20^{\circ} \mathrm{C}$. The cells were placed on ice and incubated with $10 \%$ trichloroacetic acid for an additional $10 \mathrm{~min}$. This treatment was repeated twice. Finally, the cells were solubilized with $300 \mu$ l per sample with $0.1 \mathrm{~N} \mathrm{NaOH}$ containing $0.1 \%$ SDS. Each solubilized sample was added to $4 \mathrm{ml}$ of scintillation fluid, and radioactivity (incorporation of $\left.{ }^{3} \mathrm{H}\right]$ thymidine into DNA) was measured in quadruplicate on a liquid scintillation counter.

Acknowledgements. We are grateful to Ms Shirley Smith for excellent editorial assistance. We thank Dr. N Ratner for providing us with the C57BL/6J mice with a targeted Nf1 gene allele. This work was supported by DOD Grant NF 030009 (YK and RS), the Israel Ministry of Health (YK and RS), and the Recanati Foundation for Research in Medicine (YK and RS). Yoel Kloog is the incumbent of the Jack H Skirball Chair in Applied Neurobiology.

1. Rubin JB, Gutmann DH. Neurofibromatosis type 1 - a model for nervous system tumour formation? Nat Rev Cancer 2005; 5: 557-564.

2. Martin GA, Viskochil D, Bollag G, McCabe PC, Crosier WJ, Haubruck $\mathrm{H}$ et al. The GAPrelated domain of the neurofibromatosis type 1 gene product interacts with ras p21. Cell 1990; 63: 843-849.

3. Basu TN, Gutmann DH, Fletcher JA, Glover TW, Collins FS, Downward J. Aberrant regulation of ras proteins in malignant tumour cells from type 1 neurofibromatosis patients. Nature 1992; 356: 713-715.

4. DeClue JE, Papageorge AG, Fletcher JA, Diehl SR, Ratner N, Vass WC et al. Abnormal regulation of mammalian p21ras contributes to malignant tumor growth in von Recklinghausen (type 1) neurofibromatosis. Cell 1992; 69: 265-273.

5. Guha A, Lau N, Huvar I, Gutmann D, Provias J, Pawson T et al. Ras-GTP levels are elevated in human NF1 peripheral nerve tumors. Oncogene 1996; 12: 507-513.

6. Jacks T, Shih TS, Schmitt EM, Bronson RT, Bernards A, Weinberg RA. Tumour predisposition in mice heterozygous for a targeted mutation in Nf1. Nat Genet 1994; 7: 353-361.

7. Cichowski K, Shih TS, Schmitt E, Santiago S, Reilly K, McLaughlin ME et al. Mouse models of tumor development in neurofibromatosis type 1. Science 1999; 286: 2172-2176.

8. Bajenaru ML, Zhu Y, Hedrick NM, Donahoe J, Parada LF, Gutmann DH. Astrocyte-specific inactivation of the neurofibromatosis 1 gene (NF1) is insufficient for astrocytoma formation. Mol Cell Biol 2002; 22: 5100-5113.

9. Guo HF, Tong J, Hannan F, Luo L, Zhong Y. A neurofibromatosis-1-regulated pathway is required for learning in Drosophila. Nature 2000; 403: 895-898.

10. The I, Hannigan GE, Cowley GS, Reginald S, Zhong Y, Gusella JF et al. Rescue of a Drosophila NF1 mutant phenotype by protein kinase A. Science 1997; 276: 791-794. 
11. Johnson MR, DeClue JE, Felzmann S, Vass WC, Xu G, White R et al. Neurofibromin can inhibit Ras-dependent growth by a mechanism independent of its GTPase-accelerating function. Mol Cell Biol 1994; 14: 641-645.

12. Dasgupta B, Dugan LL, Gutmann DH. The neurofibromatosis 1 gene product neurofibromin regulates pituitary adenylate cyclase-activating polypeptide-mediated signaling in astrocytes. J Neurosci 2003; 23: 8949-8954.

13. Hannan F, Ho I, Tong JJ, Zhu Y, Nurnberg P, Zhong Y. Effect of neurofibromatosis type I mutations on a novel pathway for adenylyl cyclase activation requiring neurofibromin and Ras. Hum Mol Genet 2006; 15: 1087-1098.

14. Yonish-Rouach E, Resnitzky D, Lotem J, Sachs L, Kimchi A, Oren M. Wild-type p53 induces apoptosis of myeloid leukaemic cells that is inhibited by interleukin-6. Nature 1991; 352: 345-347.

15. Raveh T, Kimchi A. DAP kinase-a proapoptotic gene that functions as a tumor suppressor Exp Cell Res 2001; 264: 185-192.

16. Dee K, Freer M, Mei Y, Weyman CM. Apoptosis coincident with the differentiation of skeletal myoblasts is delayed by caspase 3 inhibition and abrogated by MEK-independent constitutive Ras signaling. Cell Death Differ 2002; 9: 209-218.

17. Guerrero S, Casanova I, Farre L, Mazo A, Capella G, Mangues R. K-ras codon 12 mutation induces higher level of resistance to apoptosis and predisposition to anchorageindependent growth than codon 13 mutation or proto-oncogene overexpression. Cancer Res 2000; 60: 6750-6756.

18. Cox AD, Der CJ. The dark side of Ras: regulation of apoptosis. Oncogene 2003; 22 8999-9006.

19. Donovan S, See W, Bonifas J, Stokoe D, Shannon KM. Hyperactivation of protein kinase B and ERK have discrete effects on survival, proliferation, and cytokine expression in Nf1deficient myeloid cells. Cancer Cell 2002; 2: 507-514.

20. Hiatt K, Ingram DA, Huddleston H, Spandau DF, Kapur R, Clapp DW. Loss of the nf1 tumor suppressor gene decreases fas antigen expression in myeloid cells. Am J Pathol 2004; 164: 1471-1479.

21. Klesse LJ, Parada LF. p21 ras and phosphatidylinositol-3 kinase are required for survival of wild-type and NF1 mutant sensory neurons. J Neurosci 1998; 18: 10420-10428.

22. Brannan $\mathrm{Cl}$, Perkins AS, Vogel KS, Ratner N, Nordlund ML, Reid SW et al. Targeted disruption of the neurofibromatosis type-1 gene leads to developmental abnormalities in heart and various neural crest-derived tissues. Genes Dev 1994; 8: 1019-1029.

23. Cichowski K, Santiago S, Jardim M, Johnson BW, Jacks T. Dynamic regulation of the Ras pathway via proteolysis of the NF1 tumor suppressor. Genes Dev 2003; 17: 449-454.
24. Johannessen CM, Reczek EE, James MF, Brems H, Legius E, Cichowski K. The NF1 tumor suppressor critically regulates TSC2 and mTOR. Proc Natl Acad Sci USA 2005; 102 8573-8578.

25. Kloog $Y$, Cox AD. Prenyl-binding domains: potential targets for Ras inhibitors and anticancer drugs. Semin Cancer Biol 2004; 14: 253-261.

26. Kloog Y, Cox AD, Sinensky M. Concepts in Ras-directed therapy. Exp Opin Invest Drugs 1999; 8: 2121-2140.

27. Barkan B, Starinsky S, Friedman E, Stein R, Kloog Y. The Ras inhibitor farnesylthiosalicylic acid as a potential therapy for neurofibromatosistype 1. Clin Cancer Res 2006; 12 5533-5542.

28. Blum R, Nakdimon I, Goldberg L, Elkon R, Shamir R, Rechavi G et al. E2F1 identified by promoter and biochemical analysis as a central target of glioblastoma cell-cycle arrest in response to Ras inhibition. Int J Cancer 2006; 119: 527-538.

29. Dasgupta B, Gutmann DH. Neurofibromin regulates neural stem cell proliferation, survival, and astroglial differentiation in vitro and in vivo. J Neurosci 2005; 25 5584-5594.

30. Jondal M, Xue Y, McConkey DJ, Okret S. Thymocyte apoptosis by glucocorticoids and cAMP. Curr Top Microbiol Immunol 1995; 200: 67-79.

31. Rosenbaum T, Boissy YL, Kombrinck K, Brannan Cl, Jenkins NA, Copeland NG et al. Neurofibromin-deficient fibroblasts fail to form perineurium in vitro. Development 1995 121: 3583-3592.

32. Schulze KM, Hanemann CO, Muller HW, Hanenberg H. Transduction of wild-type merlin into human schwannoma cells decreases schwannoma cell growth and induces apoptosis. Hum Mol Genet 2002; 11: 69-76.

33. Hamaratoglu $F$, Willecke $M$, Kango-Singh $M$, Nolo $R$, Hyun $E$, Tao $C$ et al. The tumoursuppressor genes NF2/Merlin and expanded act through Hippo signalling to regulate cell proliferation and apoptosis. Nat Cell Biol 2006; 8: 27-36.

34. Marom M, Haklai R, Ben Baruch G, Marciano D, Egozi Y, Kloog Y. Selective inhibition of Ras-dependent cell growth by farnesylthiosalisylic acid. J Biol Chem 1995; 270 22263-22270.

35. Lindenboim L, Yuan J, Stein R. Bcl-xS and Bax induce different apoptotic pathways in PC12 cells. Oncogene 2000; 19: 1783-1793.

36. Paz A, Haklai R, Elad G, Ballan E, Kloog Y. Galectin-1 binds H-Ras to mediate Ras membrane anchorage and cell transformation. Oncogene 2001; 20: 7486-7493.

37. Lindenboim L, Haviv R, Stein R. Inhibition of drug-induced apoptosis by survival factors in PC12 cells. J Neurochem 1995; 64: 1054-1063. 